\title{
Nanoparticles as a Solution for Eliminating the Risk of Mycotoxins
}

\author{
Pavel Horky, Sylvie Skalickova *(D), Daria Baholet and Jiri Skladanka \\ Department of Animal Nutrition and Forage Production, Faculty of AgriSciences, Mendel University, \\ 61300 Brno, Czech Republic; pavel.horky@mendelu.cz (P.H.); xbaholet@mendelu.cz (D.B.); \\ jiri.skladanka@mendelu.cz (J.S.) \\ * Correspondence: sylvie.skalickova@gmail.com; Tel.: +420-5-45-133-164
}

Received: 26 July 2018; Accepted: 4 September 2018; Published: 14 September 2018

\begin{abstract}
Mycotoxins are toxic secondary metabolites produced by certain filamentous fungi. The occurrence of mycotoxins in food and feed causes negative health impacts on both humans and animals. Clay binders, yeast cell walls, or antioxidant additives are the most widely used products for mycotoxin elimination to reduce their impact. Although conventional methods are constantly improving, current research trends are looking for innovative solutions. Nanotechnology approaches seem to be a promising, effective, and low-cost way to minimize the health effects of mycotoxins. This review aims to shed light on the critical knowledge gap in mycotoxin elimination by nanotechnology. There are three main strategies: mold inhibition, mycotoxin adsorption, and reducing the toxic effect via nanoparticles. One of the most promising methods is the use of carbon-based nanomaterials. Graphene has been shown to have a huge surface and high binding capacity for mycotoxins. Attention has also been drawn to polymeric nanoparticles; they could substitute adsorbents or enclose any substance, which would improve the health status of the organism. In light of these findings, this review gives new insights into possible future research that might overcome challenges associated with nanotechnology utilization for mycotoxin elimination from agricultural products.
\end{abstract}

Keywords: mycotoxin; nanotechnology; agriculture; toxicity; nanoparticles

\section{Introduction}

Mycotoxins are produced by molds under specific conditions, such as high humidity, poor agricultural practices, or damaged and contaminated crops. Although the presence of molds on grains does not necessarily mean there are mycotoxins present, the potential for mycotoxin production does exists. Further, the long-term absence of molds on stored food and feed does not guarantee that the grain is free of mycotoxins [1,2]. The issue of mycotoxin risk is therefore tricky and requires the attention of both agrotechnology specifically and the scientific community generally.

The main producers of mycotoxins are species of Aspergillus (aflatoxins (AFL), ochratoxin A (OTA), trichothecenes, and deoxynivalenol (DON)), Fusarium (zearalenone (ZEA), fumonisins (FUM) $\mathrm{B} 1$ and B2, and the emerging mycotoxins fusaproliferin, moniliformin, beauvericin, and enniatins), Claviceps (ergot alkaloids), and Alternaria (altenuene, alternariol, alternariol methyl ether, altertoxin, and tenuazonic acid) [3]. These mycotoxins are among the most dangerous. They may cause cardiotoxicity, central nervous system disorders, gastrointestinal tract damage, nephrotoxicity, and hepatotoxicity. The mechanisms of mycotoxin toxicity have been studied for many years [4-9]. Currently, there are about 500 species of mycotoxins and it is estimated that another 1000 have yet to be discovered. Especially, masked mycotoxins pose a great risk because there is no established routine method for determining them [10]. 
Correct crop management practices play an important role in mycotoxin occurrence prevention. Furthermore, during the growing period, negative impacts on mycotoxin propagation could include drought, insect attack, temperature fluctuations, or crop rotation [11]. Humidity, grain fragments, or weeds are the major factors for mold propagation in stored materials [12].

Mycotoxins are known to cause a number of toxic effects in animal species. The most sensitive is poultry, followed by pigs and ruminants [13]. Generally, it is well known that ruminants metabolize some kinds of mycotoxins with almost 100\% efficacy [14]. Mycotoxins have the ability to become part of animal products because they are largely lipophilic [15]. For example, AFL M1 easily gets into milk, which can cause serious health problems [16].

Recent trends in mycotoxin elimination from food and feed have led to the application of various adsorbents as nutritional additives. The most used are clay particles such as bentonites and zeolites due to their opposite polarity [17]. The disadvantage of clay absorbers is their ability to bind to minerals and vitamins from feed. For this reason, the dietary content of micronutrients have to be increased by an average of $20 \%[18,19]$. Besides, clay adsorbents could be used in yeast cell walls (Saccharomyces cerevisiae) [20-22]. However, the effectiveness of mycotoxin absorbents themselves ranges from $20 \%$ to $80 \%$. A single assessment of the effectiveness of adsorbents has not yet been established.

Nevertheless, mycotoxins are an important issue in a number of disciplines such as food science, toxicology, applied and analytical chemistry, veterinary sciences, mycology, plant science, and agriculture. This topic has been studied far less from a nanotechnological point of view, although nanotechnology is a dynamically evolving discipline [23,24]. The key properties in this field of research are based on the nanoscale. For example, gravity is no longer relevant here as well as the shape and net charge, which greatly changes the behavior of the material. Nanotechnologies allow for the alteration of already discovered properties and the creation of endlessly new materials with exciting possibilities [25]. Nowadays, some of the latest developments in nanotechnology are commercially used in medicine, the household, textiles, and electrotechnics.

In this review, we focus on the key words mycotoxins, nanotechnology, nanoparticles (NPs), and agriculture. Recent research suggests that nanotechnology is increasingly penetrating the field of agriculture and mycotoxins. The first development of nanotechnological applications for mycotoxin elimination or detection have been implemented since 2009 [26]. Although several studies have already focused on the use of nanotechnology for mycotoxin elimination, these experimental results have not yet been reviewed.

\section{Mycotoxin Detection Using Nanoparticles}

Regarding mycotoxins, many analytical methods have been developed for their reliable determination. Currently, the most commonly used approaches in practice are high-pressure liquid chromatography (HPLC) and mass detection and enzyme-linked immunoassay (ELISA) [27,28]. Since early detection is needed to protect health, current research has focused on improving the detection limit, time consumption, sample consumption, and ease of use [29-32]. Practice distinguishes two different types of NP utilization in detection systems [33,34]. On the receptor level, NPs directly react with the detected molecule. This system requires adequate specificity and reproducibility. NPs could be evolved as a transducer-enhancing signal to the detector. An overview of these technologies is given by Rai et al. (2015). This work summarizes the possibilities of the immobilization of biomolecules and states that mycotoxins warrant further research regarding the construction of nanobiosensors with more stability and durability [33]. In this case, the advantage of NPs is their high surface-area-to-volume ratio, which enables the binding of higher concentrations of mycotoxins [35]. Over the past decade, research in nanomaterials has focused on carbon nanotubes, polymers, superparamagnetic NPs, quantum dots, and metal NPs. In addition, the use of nanoparticles allows various modifications with the specific ligands or surface decoration by functional groups such as $\mathrm{CH}_{3},-\mathrm{OH},-\mathrm{COOH},-\mathrm{NH}_{2}$, or $-\mathrm{CONH}_{2}$. 
Much of the current literature on mycotoxin detection pays particular attention to immunodetection of mycotoxins (Figure 1). Lateral flow immunochromatographic assay is a rapidly developing technique which combines antibodies (for specificity) and NPs (for sensitivity). Taking advantage of gold NPs of quantum dots, the limit of detection for various mycotoxins is in the range of $0.1-10,000 \mathrm{ng} / \mathrm{mL}$ [36]. Immunoelectrodes have been designed based on bismuth oxide nanorods for AFL B1 detection [37] (Figure 1a). The third generation of immunosensors is characterized by rapid response (15 s), high sensitivity $(1.132 \mu \mathrm{A} /(\mathrm{ng} / \mathrm{dL}))$, broad linear range (1-70 ng/dL), and low detection limit $(8.715 \mathrm{ng} / \mathrm{dL})$ and operates by direct electron transfer of analytes to electrodes [38]. Immunochromatographic ready-to-use test strips have recently been proposed for the simultaneous detection of ZEA and T2 toxin with detection limits of 0.1 and $0.05 \mathrm{ng} / \mathrm{mL}$. Perfect sensitivity and rapid testing have been achieved using antibody-labeled magnetic NPs for sample pretreatment [39]. Multilayer NPs can perform several functions simultaneously. ( $\mathrm{Lv}$ et al.) (2017) designed $\mathrm{RuSi} @ \mathrm{Ru}(\mathrm{bpy}) 3(2+)$ loaded with gold-functioned nanoporous $\mathrm{CO} / \mathrm{Co}_{3} \mathrm{O}_{4}$ electrochemiluminescence biosensors for sensitivity ( $5 \mathrm{pg} / \mathrm{mL}$ ) detection of DON [40]. Ag@Au Core-Shell NPs have been used for surface-enhanced Raman scattering aptasensors for the double detection of OTA A and AFL B1. Principally, Raman scattering aptasensors produce stable and quantitative signals that emerge from the plasmonic coupling at the junction of a silver core and a gold shell [41]. The latest development has focused on one-step multiplex detection of various mycotoxins. Whether in the form of a strip or whatever form is needed for a device, this simplifies the whole analysis [42] (Figure 1b). Kong et al. made semiquantitative and quantitative multi-immunochromatographic strips based on gold NPs as a label for the detection of 20 mycotoxin. An advantage of this is the ability to read results by the naked eye. The visual limits of detection for ZEAs, DONs, T2s, AFs, and FUMs were estimated to be $0.1-0.5$, $2.5-250,0.5-1,0.25-1$, and $2.5-10 \mu \mathrm{g} / \mathrm{kg}$, respectively [43].

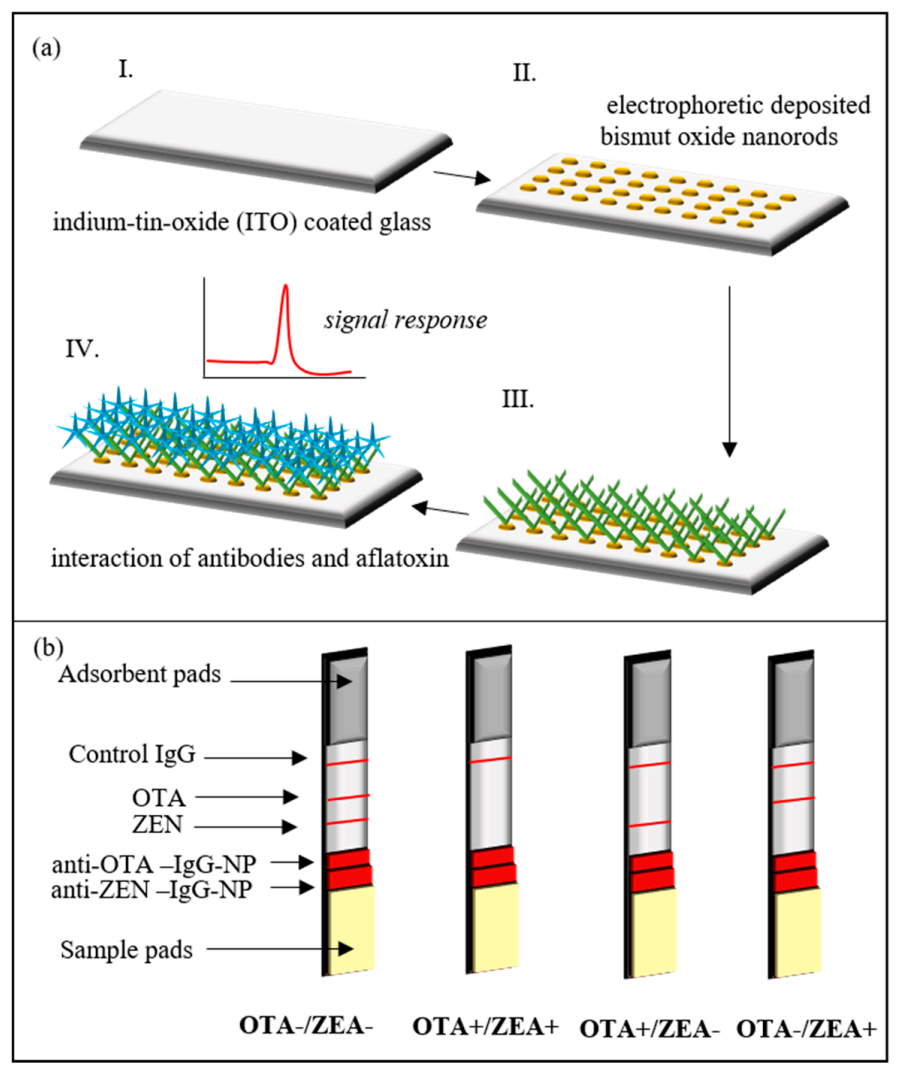

Figure 1. Different immunodetection arrangements. (a) An electrosensor based on the interaction of the antibody with mycotoxin, which amplifies the signal; (b) A lateral easy-to-use immunoassay for the detection of mycotoxins by the naked eye. Figures adapted from [37,42], with permission from Elsevier (2017) and John Wiley and Sons (2015), respectively. 
The abovementioned findings demonstrate the great potential of NPs for mycotoxin detection. Therefore, detection requirements are greater than sensitivity and reliability. Mycotoxin derivates are commonly undetectable by conventional analytical techniques due to their changed structure by plant enzymes [44]. Enzymatic or acid hydrolysis is often employed prior to mycotoxin determination as an effective pretreatment step of masked derivates [45]. Also, mass spectrometry could expose masked mycotoxins [46-48]. The design of a proof of concept for the identification of unknown modified masked mycotoxins is still a big challenge, which could be facilitated with NPs for both mycotoxin isolation or detection.

\section{Nano Approaches for Mycotoxin Risk Elimination}

Recently, questions have been raised about the nanotechnology solution of mycotoxin risk. There are three general strategies: mold inhibition, mycotoxin adsorption, and impact elimination.

\subsection{Antifungal Nanomaterials Cause Mold Inhibition and Mycotoxin Production}

The past decade has seen the rapid development of antibacterial nanoparticles as a solution for antibiotic resistance of pathogenic bacteria. Their applicability against mycotoxin occurrence has been limited by differences between bacteria and fungi. Bacteria are single celled, whereas most fungi are multicellular; bacteria have three distinct shapes, while fungi have various shapes which lead to mycelium formation; bacteria reproduce sexually, whereas fungi are capable of reproducing both sexually or asexually. All these differences make fungi more durable and resistant against some antibiotics [49]. Until now, research has tended to focus on antibacterial nanoparticles rather than on nanoparticles against fungi. The latest findings in the field of antifungal nanoparticles have been summarized between 2016 and 2017 [50-54]. In practice, the prevention of mycotoxin occurrence could be mediated via antifungal nanoparticles, which are easy to produce in large scale. According to recent scientific articles (summarized in Tables 1 and 2), the antifungal strategy is oriented in two directions. Firstly, an antifungal compound is encapsulated into a polymeric nanocage. Perhaps the most serious disadvantage of this method is the instability in air, although nanopolymers allow cargo release under the appropriate conditions (e.g., presence of enzymes, higher temperature, $\mathrm{pH}$ change). Secondly, inhibition effect is reached by nanoparticles alone. This method mainly relies on metal nanoparticles which are stable, act immediately, and offer the possibility of green synthesis. Moreover, the advantage of green synthesis is the formation nanobiocomposites using plant, micro-organism, and animal sources which show less toxicity and improved their main features (Table 2) [55].

Table 1. Antifungal nanoparticles synthetized by the chemical route.

\begin{tabular}{|c|c|c|c|c|}
\hline Organism & Type of Particles & Inhibition Dose & Average Size & Reference \\
\hline Alternaria brassicicola & Silver nanoparticles & 100 ppm & NA & [56] \\
\hline Alternaria solani & Silver nanoparticles & $10 \mathrm{ppm}$ & $14 \mathrm{~nm}$ & [57] \\
\hline $\begin{array}{l}\text { Alternaria solani and } \\
\text { Sclerotium rolfsii }\end{array}$ & PEGylated Mancozeb & $3 \mathrm{mg} / \mathrm{L}$ & NA & [58] \\
\hline Aspergillus flavus & $\begin{array}{l}\text { Thyme essential oils in } \\
\text { chitosan-benzoic acid nanogel }\end{array}$ & $300 \mathrm{mg} / \mathrm{L}$ & $100 \mathrm{~nm}$ & [59] \\
\hline Aspergillus flavus & $\begin{array}{l}\text { Menthe piperita essential oils in } \\
\text { chitosan-cinnamic acid nanogel }\end{array}$ & 500 ppm & $100 \mathrm{~nm}$ & [60] \\
\hline Aspergillus flavus & $\begin{array}{l}\text { Cuminum cyminum essential oils } \\
\text { in chitosan-caffeic acid nanogel }\end{array}$ & 650 ppm & $100 \mathrm{~nm}$ & [61] \\
\hline Aspergillus flavus & $\begin{array}{l}\text { Nanodispersed Cinnamaldehyde } \\
\text { by surfactant (Tween } 80 \text { ) }\end{array}$ & $1.0 \mathrm{mM}$ & $60 \mathrm{~nm}$ & [62] \\
\hline Aspergillus flavus & Silver nanoparticles & $5 \mu \mathrm{g} / \mathrm{mL}$ & $4.5 \mathrm{~nm}$ & [63] \\
\hline Aspergillus flavus & Titanium dioxide nanoparticles & $1 \mathrm{~g} / \mathrm{L}$ & $30 \mathrm{~nm}$ & [64] \\
\hline Aspergillus niger & $\begin{array}{l}\text { Silver-, copper-, and nickel-based } \\
\text { nanoparticles }\end{array}$ & $65 \mu \mathrm{g} / \mathrm{mL}$ & $15 \mathrm{~nm}$ & [65] \\
\hline Aspergillus niger & Pullulan and silver nanoparticles & $1.7 \mathrm{mg} / \mathrm{g}$ & $9 \mathrm{~nm}$ & [66] \\
\hline
\end{tabular}


Table 1. Cont

\begin{tabular}{|c|c|c|c|c|}
\hline Organism & Type of Particles & Inhibition Dose & Average Size & Reference \\
\hline Aspergillus parasiticus & Citrate-coated silver nanoparticles & $50 \mathrm{ng} / \mathrm{mL}$ & $20 \mathrm{~nm}$ & [67] \\
\hline Aspergillus parasiticus & Silver nanoparticles & $180 \mu \mathrm{g} / \mathrm{mL}$ & NA & [68] \\
\hline Fusarium culmorum & Silver nanoparticles & $20 \mathrm{mg} / \mathrm{L}$ & $35 \mathrm{~nm}$ & [69] \\
\hline Fusarium graminearum & Chitosan nanoparticles & 5000 ppm & $200 \mathrm{~nm}$ & [70] \\
\hline Fusarium oxysporum & Chitosan silver nanocomposites & $100 \mu \mathrm{g} / \mathrm{mL}$ & $370 \mathrm{~nm}$ & [71] \\
\hline Fusarium oxysporium & Alumina nanoparticles & $400 \mathrm{mg} / \mathrm{L}$ & $200 \mathrm{~nm}$ & [72] \\
\hline Fusarium solani & $\begin{array}{l}\text { Ag-doped Titan oxide } \\
\text { nanoparticles }\end{array}$ & $0.43 \mathrm{mg} /$ plate & NA & [73] \\
\hline $\begin{array}{l}\text { Penicillium expansum } \\
\text { and Botrytis cinerea }\end{array}$ & Zinc oxide nanoparticles & $3 \mathrm{mmol} / \mathrm{L}$ & $70 \mathrm{~nm}$ & [74] \\
\hline $\begin{array}{l}\text { Penicillium digitatum } \\
\text { and Fusarium solani }\end{array}$ & Copper nanoparticles & 20 and $60 \mu \mathrm{g} / \mathrm{mL}$ & NA & [75] \\
\hline Penicillium verrucosum & Silica and silver nanoparticles & 5-100 ppm & $\begin{array}{l}0.65 \mathrm{~nm} \text { and } \\
200 \mathrm{~nm}\end{array}$ & [76] \\
\hline Penicillium and Mucor & Zinc oxide nanoparticles & $5 \mathrm{mg} / \mathrm{mL}$ & $600 \mathrm{~nm}$ & [77] \\
\hline
\end{tabular}

Table 2. Antifungal green synthetized nanoparticles.

\begin{tabular}{|c|c|c|c|c|c|}
\hline Organism & Mediator & Type of Particles & Inhibition Dose & Average Size & Reference \\
\hline Aspergillus sp. and & Aloe vera leaf extract & $\mathrm{Ag}$ & $100 \mu \mathrm{L}$ of $1 \mathrm{M}$ & $70 \mathrm{~nm}$ & [78] \\
\hline Aspergillus ochraceus & $\begin{array}{l}\text { Aspergillus terreus and } \\
\text { Penicillium expansum }\end{array}$ & $\mathrm{Ag}$ & 3 and $9 \mathrm{~g} / 100 \mathrm{~mL}$ & $20 \mathrm{~nm}$ & [79] \\
\hline $\begin{array}{l}\text { Aspergillus niger and } \\
\text { Aspergillus flavus }\end{array}$ & Cissus quadrangularis & $\mathrm{CuO}$ & 1000 ppm & $30 \mathrm{~nm}$ & [80] \\
\hline Aspergillus flavus & Penicillium citrinum & $\mathrm{Ag}$ & 4000 ppm & $54 \mathrm{~nm}$ & [81] \\
\hline $\begin{array}{l}\text { Aspergillus fumigatus } \\
\text { and Candida albicans }\end{array}$ & Bacillus species & Se & $100 \mu \mathrm{g} / \mathrm{mL}$ & $140 \mathrm{~nm}$ & [82] \\
\hline $\begin{array}{l}\text { Candida, Aspergillus, } \\
\text { and Fusarium }\end{array}$ & Arthroderma fulvum & $\mathrm{Ag}$ & $1 \mathrm{mg} / \mathrm{mL}$ & $15 \mathrm{~nm}$ & [83] \\
\hline Fusarium & Chaetomium globosum & $\mathrm{Ag}$ & $500 \mathrm{mg} / \mathrm{L}$ & $15 \mathrm{~nm}$ & [84] \\
\hline
\end{tabular}

The relationship between an NP's antifungal activity and mechanism of action has been investigated. He et al. studied the influence of $\mathrm{ZnO}$ nanoparticles on Botrytis cinerea and Penicillium expansum. ZnO NPs producing reactive oxide species (ROS) leads to the damage of the lipid bilayer cell membrane and the breakdown of the affected cell [74]. Scanning electron microscopy (SEM) showed the formation of unusual bulges on the surface of fungal hyphae and deformation of fungal hyphae after treatment with $12 \mathrm{mmol} / \mathrm{L} \mathrm{ZnO}$ NPs. More recent attention has been focused on silver nanoparticles. The findings indicate that Ag NPs inhibit fungal growth as well as morphological and metabolic changes $[85,86]$. For instance, the application of 45 ppm Ag NPs caused a decrease of organic acid (oxalic, maleic, and citric acid) production, mycotoxin production (up to $80 \%$ ), and changes in the enzymatic profile in Aspergillus niger and Penicillium chrysogenum [85]. All the studies reviewed so far, however, suffer from the fact that the interaction of NPs with the individual components of the fungi cells has not been investigated yet.

\subsection{Nanoparticles Suitable for Mycotoxin Adsorption}

The high expectations of using nanomaterials as special adsorbents to remove pollutants relies not only on the high surface area and the high affinity to organic compounds (properties of conventional adsorbents such as those possessed by activated carbon) but also greatly on the fact that nanomaterials can be engineered or modified specifically to enhance selectivity to specific target pollutants [87]. Mycotoxins show a structural diversity resulting in different chemical and physical properties. Mycotoxins can be classified as polar or nonpolar molecules; however, there are several that fall in between. AFLs and FUMs are highly polar, while trichothecenes are polar and ZEAs are nonpolar [88,89]. This diversity could be resolved by such a material that changes its properties under various physicochemical conditions and can denote both polar and nonpolar 
substances [87]. The following subsections describe the most promising nanomaterials for the elimination of mycotoxins.

\section{Carbon Nanostructures}

Activated charcoal has been used for mycotoxin elimination for a long time. From this established practice proceeds the use of carbon nanoforms as a promising successor to activated carbon. The advantages of carbon nanomaterials are excellent stability, inertness, high adsorptive properties, large surface area per weight, and colloidal stability upon various pHs, which is important to preserve in the gastrointestinal tract [90]. Chemically, the carbon-carbon covalent bonds and crystalline structure provide specific properties such as strength, elasticity, and great conductivity. Graphene, graphene oxide, nanodiamonds, fullerenes, fiber, and nanotubes have a great potential to become novel adsorbents of mycotoxins. Nanocarbon structures are amphoteric and their surface could be protonated or deprotonated, which results in the binding capacity of polar or nonpolar compounds. Binding activity properties of carbon nanomaterials are summarized in Figure 2. Generally, carbon nanotube adsorption affinity poorly correlates with hydrophobicity but increases in the order of nonpolar aliphatic < nonpolar aromatics < nitroaromatics functional groups [91].

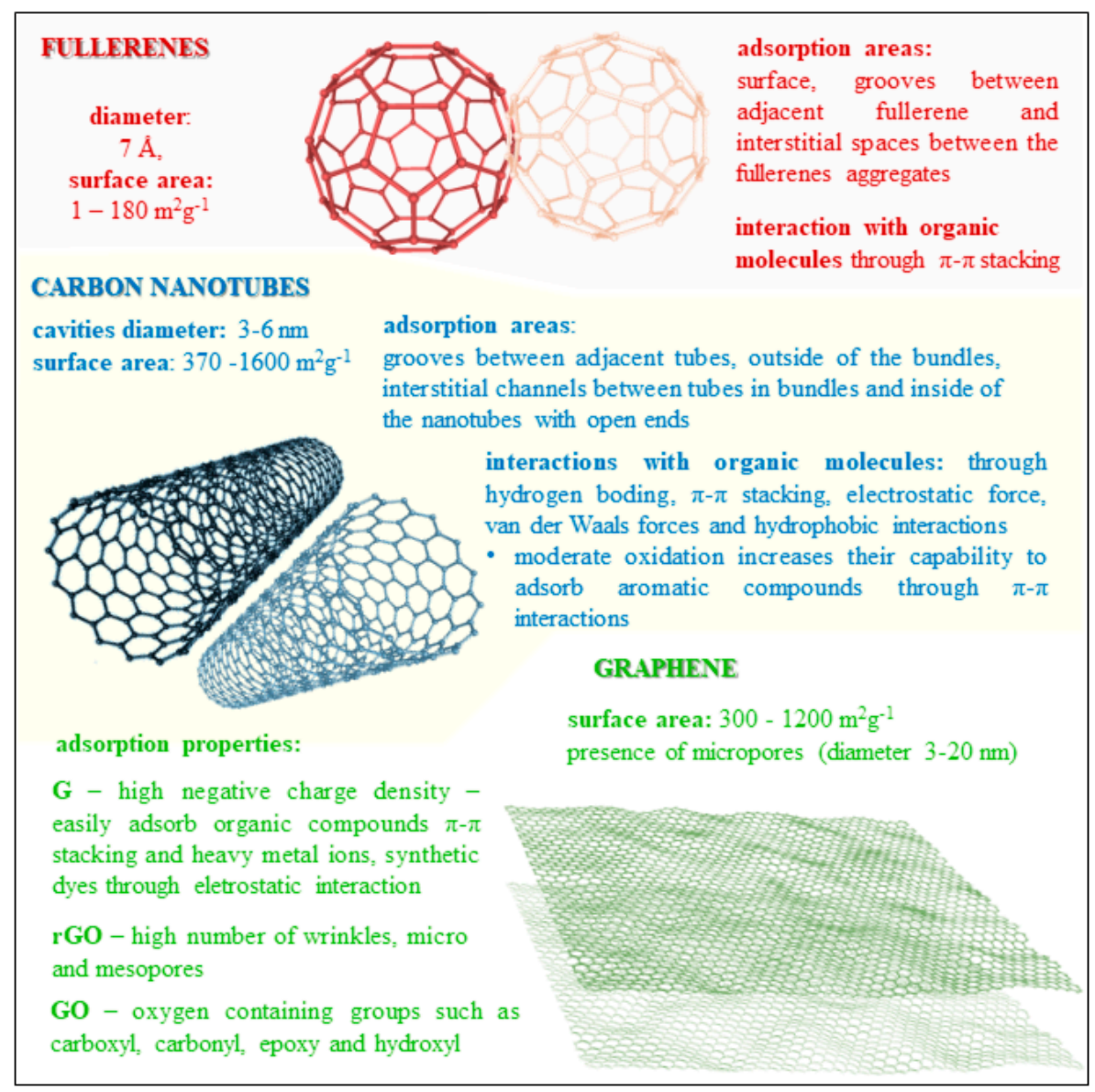

Figure 2. Key properties of carbon nanoparticles such as fullerenes, carbon nanotubes, and graphene (native graphene $(\mathrm{G})$, reduced graphene (rGO), and graphene oxide $(\mathrm{GO})$ ). Mycotoxins can be bound to the surface, bundles, grooves, or channels between nanoparticles via different binding interactions.

Fullerene adsorption behavior was found to be higher than that of activated carbon. Preliminary investigations of fullerenol $\mathrm{C}_{60}(\mathrm{OH})_{24}$ nanoparticles on mycelial growth, aflatoxin production, and oxidative stress modulation in an aflatoxigenic strain of Aspergillus flavus showed slightly reduced mycelial biomass weight but significantly decreased aflatoxin concentration in media. A concentration 
$10 \mathrm{ng} / \mathrm{mL}$ of fullerenol reduced aflatoxin production compared to a control sample [92]. The possible mechanism could be explained by oxidative stress suppression of fungal culture [93].

Nanodiamonds show all the benefits of carbon nanomaterials and their large-scale production is considered to be inexpensive. Their chemical structure allows surface functionalization, including carboxylation, hydrogenation, and hydroxylation, which could provide binding affinity to various types of the mycotoxins. Nanodiamond aggregates $(\sim 40 \mathrm{~nm})$ tend to adsorb AFL B1 and OTA via electrostatic interactions that depend on the types functional groups on the surface of nanodiamonds [94]. The adsorption capacity was estimated for AFL B1 as approximately $10 \mu \mathrm{g}$ per $\mathrm{mg}$ of nanodiamonds and for OTA around $15 \mu \mathrm{g}$ per mg of nanodiamonds. These results indicate greater adsorption capacities than commercially used yeast cell walls and clay minerals [95].

The perspective of single/multiwalled carbon nanotubes (CNT) should also be mentioned at this point. To date, CNTs are experimentally used for various medicinal applications such as drug administration, target therapy, or diagnostics in humans. In vivo experiments on mouse models indicated the absence of a pronounced toxic effect under conditions of a short-term experiment. On contrary, nanotubes affected mouse gastrointestinal mucosa and induced a weak immune response based on CNT modification and functionalization [96,97]. Nevertheless, their good adsorption capacity is well utilized in solid phase extraction protocols mainly for zearalenone [98-100], trichothecenes [101-103], and aflatoxins [104].

Magnetic graphene (MGO) synthesized from iron oxide nanostructures and graphene oxide is inexpensive and easily accessible. Numerous oxygen functional group on the MGO surface enable interaction with fusarium mycotoxins (DON, T1, and T2). An adsorption procedure was performed by dissolving palm kernel cake in water $\left(6.2 \mathrm{pH}\right.$ for $5.2 \mathrm{~h}$ at $\left.40.6^{\circ} \mathrm{C}\right)$ and subsequently MGO with bounded mycotoxins was removed via magnet. Results showed that the reduction of mycotoxins varied from $40 \%$ to $70 \%$ for T2 and DON, respectively [105]. Surface active maghemite nanoparticles (SAMN) constituted of stoichiometric maghemite $\left(\gamma-\mathrm{Fe}_{2} \mathrm{O}_{3}\right)$ showed chelating properties for citrinin and OTA toward iron(III) presence [106]. Monascus suspensions were treated with $1 \mathrm{gL}^{-1}$ SAMNs, leading to $70 \%$ citrinin removal for the first time. A second treatment removed citrinin below the analytical detection limits $\left(0.25 \mathrm{mg} \mathrm{L}^{-1}\right)$. SAMNs represent an ideal material, as their synthetic protocol is suitable for being scaled up to an industrial level and is carried out in water without using of any organic solvent [106].

\section{Chitosan Polymeric Nanoparticles}

Chitosan (CS) is a natural cationic polysaccharide produced from chitin, which is the structural element found in the exoskeleton of crustaceans. In contrast to similar polysaccharide celluloses, CS contains hydroxyl groups, acetylamine, or free amino groups which has attracted attention in many fields of applications. CS is nontoxic, biodegradable, and possesses low immunogenicity. Therefore, CS has shown promising results for mycotoxin elimination from different raw materials. In 1990s, CS began to be considered as a suitable mycotoxin adsorbent with approximately $70 \%$ efficacy [107]. In addition, a CS solution in a mixture with the minerals rektorit and attapulgit has been patented for removing feed zearalenone and reducing diarrhea due to its antimicrobial properties [108].

Although carbon nanostructures are the focus of much research nowadays, chitosan polymer and nanoparticles have been highlighted in the years 2010-2015. CS is easily subjected to nanoparticles via the gelatation process using aldehydes (e.g., glutaraldehyde) and acids (e.g., thioglycolic, acrylic, and oxalic acids) [109]. Another way for nanoparticle formation is ionic cross links based on electrostatic interaction with phosphoric acid derivatives such as sodium tripolyphosphate (TPP) [110]. Chitosan's ability to quickly gel relies on the formation of inter- and intramolecular cross linkages between TPP phosphates and chitosan amino groups. The properties of prepared CS nanoparticles depends on physicochemical conditions such as $\mathrm{pH}$, temperature, time, and functionalization or modification by specific ligands [111,112]. 
It is widely known that CS NPs are able to encapsulate various compounds. Glutaraldehyde crosslinked chitosan showed promising adsorption ability for AFL B1 (73\%), OTA (97\%), ZEN (94\%), and FUM 1 (99\%) but no obvious adsorption for DON and T2 $(<30 \%)$ in a buffer system simulating gastrointestinal conditions [113]. Although having great binding capacity, glutaraldehyde is considered to be toxic. $\mathrm{LD}_{50}$ for rats has been determined to be $1.30 \mathrm{~mL} \mathrm{50 \%} \mathrm{a.i.} / \mathrm{kg}$ body wt. On the other hand, TPP is a nontoxic, anionic chelating agent forming stable CS NPs. Using a water-in-oil microemulsion encapsulation method, magnetic $\mathrm{Fe}_{3} \mathrm{O}_{4} \mathrm{CS}$ NPs were synthetized as patulin adsorbents with high magnetic properties, adsorption capabilities, and hypotoxicity. Patulin molecules were adsorbed completely after $5 \mathrm{~h}$ with an adsorbent concentration of $400 \mu \mathrm{g}$ in conditions mimicking the $\mathrm{pH}$ of juice. In vitro cytotoxicity and acute toxicity tests showed negligible cytotoxicity, no toxic response, or histopathology in treated mice [114].

Nanoclay Binders

This group includes minerals that are used for the detoxification of mycotoxins from food and feed, such as montmorillonite, bentonite, zeolite, or hydrated sodium (calcium) aluminosilicate. Their specificity is the willingness to form multiphase solid materials where one of the phases has one, two, or three dimensions of less than $100 \mathrm{~nm}$, e.g., montmorillonite. Montmorillonite nanocomposite $(\mathrm{MN})$ has been introduced as a perspective sorptive additive possessing sizable surface area, higher porosity, strong cation exchange activities, and more active sites, which enable its interaction with mycotoxins [115]. The in vitro obtained adsorption capacity of MN for AFL was estimated to be $66.67 \mu \mathrm{g} / \mathrm{mg} \mathrm{MN}$. In vivo testing in broilers demonstrated no toxic effect with a $3 \mathrm{~g} / \mathrm{kg}$ diet [116]. Moreover, $\mathrm{MN}$ addition increased super oxide dismutase and glutathione peroxidase activities and simultaneously reduced malondialdehyde levels. Modified nanomontmorillonite by organic cations (cetyltrimethylammoniumbromide) increased the hydrophobicity of the surface of the mineral and showed a high affinity for AFLs, ZEA, and FUM B1 adsorption in rat models in vitro [117].

Unlike nanocomposites, halloysite $\left(\mathrm{Al}_{2} \mathrm{Si}_{2} \mathrm{O}_{5}(\mathrm{OH})_{4}\right)$ naturally occurs as a small cylinder (nanotubes) that has a wall thickness of 10-15 atomic alumosilicate sheets, an outer diameter of $50-60 \mathrm{~nm}$, an inner diameter of $12-15 \mathrm{~nm}$, and a length of $0.5-10 \mu \mathrm{m} \mathrm{[118].} \mathrm{Its} \mathrm{outer} \mathrm{surface} \mathrm{is}$ mostly composed of $\mathrm{SiO}_{2}$ and the inner surface of $\mathrm{Al}_{2} \mathrm{O}_{3}$, and, hence, those surfaces are oppositely charged [119]. The external siloxane and internal aluminol surface of halloysite is efficient as an absorbent (described above) or could be used as a carrier for drugs [120-123], nucleic acids [124], antibacterial agents [125], and antioxidants [119,126-130]. Therefore, halloysite is an efficient adsorbent both for cations and anions. Moreover, halloysite nanotubes could be modified by various surfactants to enhance their sorption properties and specificity [131]. For instance, stearyldimethylbenzylammonium chloride has been shown to improve protection efficacy against the detrimental effects of ZEN exposure [132]. The ZEN sorption properties in vitro by modified halloysite nanotubes were investigated from simulated gastric fluid and simulated intestinal fluid. Adsorption efficiency for ZEN was estimated to be $1 \mathrm{mg} / \mathrm{mL}$ after $120 \mathrm{~min}$. The results indicated mitigated toxic and estrogenic effects of ZEN, including changes in oxidative stress biomarkers and organ weights in rat animal model [133]. Promising results have been published in another study that focused on a comparison of ZEN toxicity with and without halloysite addition and its impact on swine kidney. ZEN treatment significantly increased biochemical parameters, inflammatory cytokines, and degenerative changes in the kidney and induced oxidative damage in plasma. Moreover, the addition of halloysite in combination with ZEN induced a re-establishment of biochemical parameters, plasma oxidative stress enzyme activities, and the normal histology of the kidney [134]. An implication of this is the possibility that halloysite is a prospective mycotoxin adsorbent due to its safety for micro-organisms, worms, fish, and small animals $[135,136]$. 


\section{Prospective Use as Antibodies}

Nanomaterials are not only promising sorbents but are also able to couple different molecules such as antibodies or targeting peptides. The application of antibodies has been highly developed in the field of medicine and target drug therapy $[137,138]$. Briefly, there are three ways of antibody conjugation on the surface of NPs: by adsorption, by direct covalent linkage between the surface of the NP and the antibody, or by using adapter molecules such as streptavidin and biotin. Direct coupling via adsorption requires specific surface properties which allow the interaction with antibody. Preferably, covalent attachment of the antibody allows interaction with antigen binding sites. For this purpose, carboxylic acids, which is the most common group present on NP surfaces (especially carbon nanostructures), could be employed for reaction with ligands. The prerequisite for effective antibody binding is the production of a stable association, a controlled amount of immobilized antibody, and the preservation of antibody activity [139-142].

In recent years, there has been increasing interest in sample pretreatment using antibody-decorated magnetic nanoparticles. This technique would facilitate purification by magnetism and combine a high capacity for purification with fast dispersibility due to the small size of the particles. It was estimated that during a 5-min purification step, an average of $80 \%$ of the ZEN and AFL B 1 returns from mycotoxin-contaminated feed mixture $(10-50 \mathrm{ng} / \mathrm{mL})$ was achieved [143]. Nanobodies $(\mathrm{Nb})$ are derived from heavy chains of antibodies. Magnetic beads carrying poly (acrylic acid) brushes (MB@PAA) were fabricated as an "Nb container" for improving AFL B1 adsorption capacity. The achieved binding capacity of $0.23 \mathrm{mg} \cdot \mathrm{g}^{-1}$ was reached [144]. In the case of magnetic separation of mycotoxins, there is no need to restrict this to chemically synthetized nanoparticles, as natural maghemite nanoclusters produced by magnetotactic bacteria can be employed with satisfactory results $[145,146]$. On the surface of magnetosomes, antimycotoxin antibodies can be easily attached as well as on chemically synthetized nanoparticle [147]. Future research should therefore concentrate on the investigation of the biological synthesis of nanoparticles for magnetic separation of mycotoxins from food and feed.

\subsection{Nanomaterials that Impact Mycotoxin Elimination from Affected Organisms}

Previous studies have reported that actual exposure to mycotoxins leads to higher oxidative stress in organisms $[148,149]$. Because an effective antidote does not exist, nutritional supplements could suppress the toxic impact of mycotoxin, decrease tissue damage caused by oxidative stress, and allow the body to sustain a viable immune system that can eradicate the pathogen. For instance, higher doses of natural antioxidants such as tocopherol, selenium, or zinc are recommended in animal feed [150,151]. In recent years, it was found that cerium, zinc (titanium) oxide, silver, gold, selenium, or carbon-based nanoparticles show unique antioxidant properties [152-154]. Moreover, better antioxidant properties of metal nanoparticles could be reached by green synthesis. It is well known that green-synthetized nanoparticles are enriched with natural compounds, which leads to their better donor activity [155]. Although their effectiveness against mycotoxin intoxication has been not explored yet, their beneficial impact on organisms should be assumed.

Polymeric nanocapsules are able to protect and deliver antioxidants to the target tissue. Ideally, the compound is transported to the target site where it is gradually released from the transporter. The protective role of chitosan nanoparticles singly, plus quercetin (Q) at low (140 mg/kg b.w.) or high ( $280 \mathrm{mg} / \mathrm{kg}$ b.w.) doses, was investigated against OTA-induced toxicity on mice. $Q$ is a member of the flavonoids family and it is well known that $Q$ has wide bioactivity, including hypolipidemic and antioxidant properties. Previous studies have reported that $Q$ showed a protective effect against the toxic effect of mycotoxins such as aflatoxin [156,157], OTA [158-160], T2 [161], zearalenone [162,163], and alternariol [164]. Round-shaped nanoparticles consisting of quercetin showed a protective effect on OTA-treated rats ( $3 \mathrm{mg} / \mathrm{kg}$ diet). CS-NPs/Q-supplemented animals showed significant improvements in food intake, body weight gain, serum biochemical parameters, histological picture and histochemical analyses, antioxidant enzymes such as glutathione peroxidase (GPx), super-oxide dismutase (SOD) 
and catalase (CAT) and malondialdehyde (MDA), DNA fragmentation, and gene expression due to minimal changes in serum biochemical parameters in comparison with untreated mice models [165]. Combined treatment with Q and CS NPs enhanced the ability to donate Q protons. Figure 3 presents a possible mechanism of action of Q-loaded CS nanoparticles via the Keap1-Nrf2 pathway (200 nm).

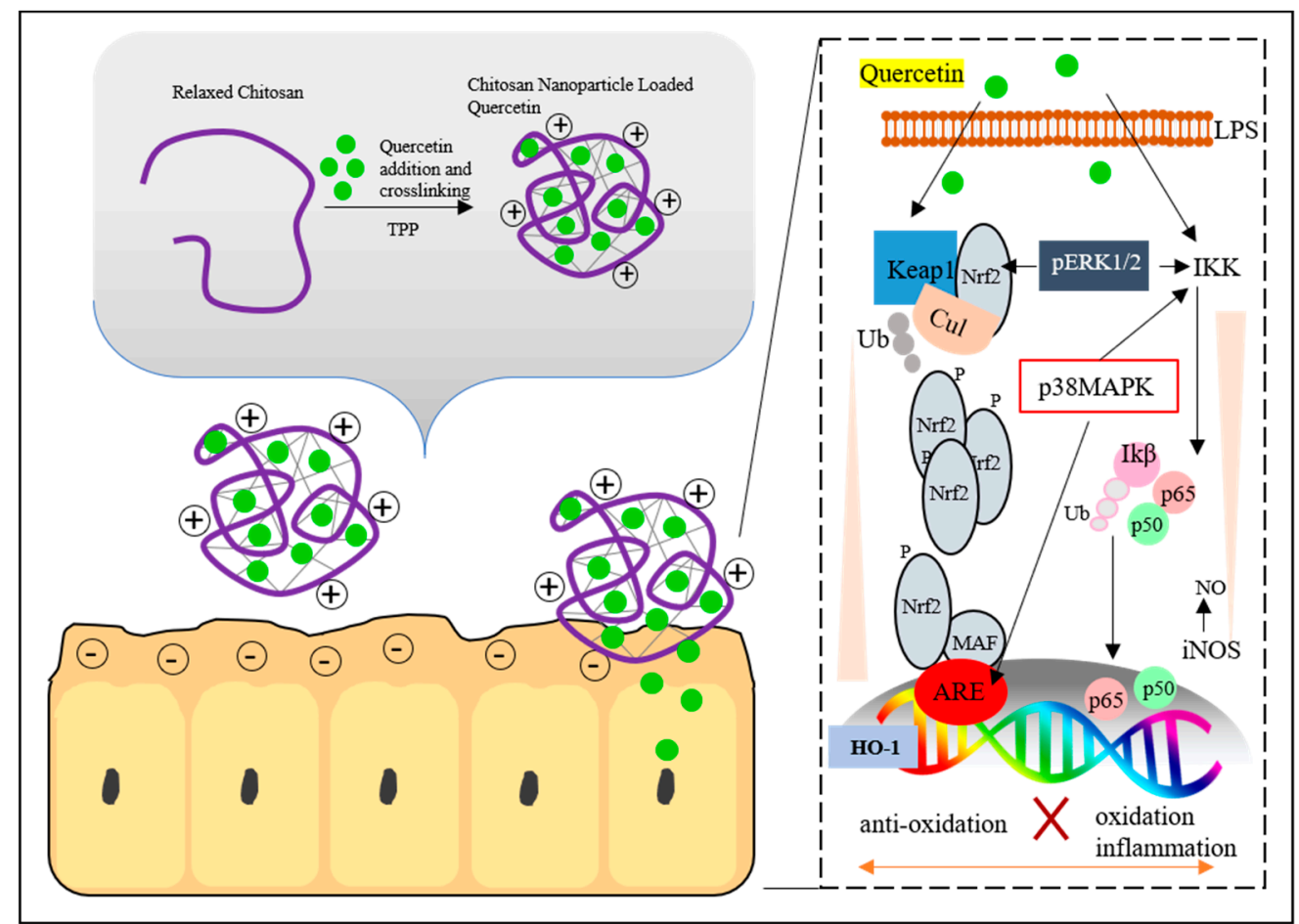

Figure 3. Scheme of the quercetin (Q)-loaded chitosan (CS) nanoparticle mechanism of action. The relaxed polysaccharide structure of the chitosan is crosslinked with tripolyphosphate (TPP). The $Q$ is entrapped in the CS structure. The positive charge of NPs electrostatically interacts with the negatively charged epithelial cell wall. Quercetin triggers a hepato-protective cascade that leads to antioxidant protection via stimulation of nuclear factor E2-related factor 2 (Nrf2)-induced heme-oxygenase-1 (HO-1) production. Transcriptional response is mediated by the acting element termed (ARE) found in the promoters of genes encoding the detoxication enzymes. Q-inhibited lipopolysacharide (LPS) induced nitric oxide synthase (iNOS) and NO production via IkB kinase (IKK) and p38 mitogen-activated protein kinases (p38MAPK). The proposed mechanism of action of quercetin is adapted from [166], with permission from Public Library of Science, 2015.

\section{Efficiency Evaluation of Nanoparticles as a Solution for Eliminating the Risk of Mycotoxins}

The issue of nanomaterials has received considerable critical attention regarding their toxicity on the living organisms. In addition, the massive increase of nanotechnology in many applications has caused the emergence of an opposing discipline (nanotoxicology). It could be assumed that newly synthetized nanoparticles are immediately examined for their toxicity and applicability. Nanotoxicity depends on particle solubility, surface area, number of particles per volume, surface charge, size, and tendency to agglomerate, which determine the elimination nanoparticles from the body [167]. The mentioned properties indicate the mechanism of action. Among those that have been described are the interaction with cell membrane, apoptosis induction, ROS production, inhibition of mitochondrial functions, lipid peroxidation, or autophagy [168]. Experimental studies have proven that nanoparticles could act as oxidative stress inductors, cytotoxically, as inflammatory agents, or could interact with nucleic acids and thereby contribute to the damage of both microorganisms and higher plants and humans [169]. Current toxicologic studies have found that the most organism-friendly are cerium oxide nanoparticles, fullerenes, or polymeric nanoparticles (Polyethylenglycol or chitosan). On the 
other hand, many inorganic nanoparticles have been considered as hazardous [170]. An objective assessment of toxicity seems to be difficult. A number of publications have been created on this topic and consortia and research groups have emerged as well. So, the status of this issue is still evolving. Interestingly, particle toxicity often works differently on model stem cells and organs. Furthermore, viability tests, such as the MTT assay, are sensitive to $\mathrm{pH}$ and medium, as found Jo et al. [171]. The relationship between the dose and the response of the organism must be taken into account as well as the accumulation in the environment and the chronic exposure of the organism to low doses [172-174].

In terms of efficiency evaluation, the toxicity of antimycotoxin nanomaterials and the toxic effect of mycotoxins have to be carefully considered. A key problem with nanomaterial efficiency against mycotoxin evaluation is the uncomplicated studies that are unilaterally focused. In reviewing the literature, no relevant data was found on the association between nanomaterial effectivity, toxicity, and the received dose of mycotoxins from food and feed. There are predominantly studies that focus on nanoparticle synthesis. Large-scale production has been improved by the fact that the prices of nanoparticles (listed in Table 3) are comparable to those of commonly used bentonite for the elimination mycotoxins from feed (2-8 USD per gram in the Czech Republic). Therefore, our intention was to outline the relationship between the threat of concentration of mycotoxins taken from food and the effectiveness of nanoparticles to eliminate them (Table 3). Nanoparticle efficiency against mycotoxins (AFL, OTA) vary from 0.065 to $1000 \mu \mathrm{g} / \mathrm{mg}$ depending on the nanomaterial used (magnetic graphene oxide < maghemite and halloysite nanoparticles < nanodiamonds < montmorillonite nanocomposite < chitosan nanoparticles). The scientific literature shows the toxic effect of the most common mycotoxins to be in the range of $1-30 \mathrm{mg} / \mathrm{kg}$ of the feed dose [175]. Theoretically, only $30 \mathrm{mg}$ of nanoparticles per $1 \mathrm{~kg}$ of compound feed is sufficient to eliminate the toxic effect. In the case of the toxicity of selected nanoparticles, we have found from the literature that the safe level for mice is on average $0.3-16,000 \mathrm{mg} / \mathrm{kg}$. Taken together, the results of nanoadsorbent efficiency against mycotoxins would have been far more persuasive if the authors had considered the actual practical feed dose of mycotoxins.

Table 3. Binding capacity and dose evaluated as safe in mouse models for selected mycotoxin nanoadsorbents.

\begin{tabular}{|c|c|c|c|c|c|c|c|c|}
\hline Nanostructure & Preparation Method & Ref. & USD/g & $\begin{array}{l}\text { Dose Evaluated } \\
\text { as a Safe in } \\
\text { Mouse Models }\end{array}$ & Ref. & Mycotoxin & $\begin{array}{l}\text { Binding } \\
\text { Capacity }\end{array}$ & Ref. \\
\hline Nanodiamonds & $\begin{array}{l}\text { ion and laser bombarding, CVD, } \\
\text { hydrothermal, ultrasonic, } \\
\text { electrochemical }\end{array}$ & [176] & $20-100$ & $<25 \mathrm{mg} / \mathrm{kg}$ & [177] & $\begin{array}{l}\text { AFL } \\
\text { OTA }\end{array}$ & $\begin{array}{l}10 \mu \mathrm{g} / \mathrm{mg} \\
15 \mu \mathrm{g} / \mathrm{mg}\end{array}$ & [108] \\
\hline $\begin{array}{c}\text { Magnetic } \\
\text { graphene oxide }\end{array}$ & $\begin{array}{l}\text { coprecipitation, covalent bonding, } \\
\text { electrostatic self-assembly, } \\
\text { impregnating graphene oxide with } \\
\text { magnetic nanoparticles }\end{array}$ & [178] & $8-20$ & $0.3 \mathrm{mg} / \mathrm{kg}$ & [179] & DON, ZEA & $0.065 \mu \mathrm{g} / \mathrm{mg}$ & \\
\hline $\begin{array}{l}\text { Surface active } \\
\text { maghemite } \\
\text { nanoparticles }\end{array}$ & $\begin{array}{l}\text { coprecipitation, sol-gel synthesis, } \\
\text { microemulsion, flow injection } \\
\text { synthesis, hydrothermal synthesis, } \\
\text { flame spray pyrolysis, } \\
\text { decomposition of organic precursors } \\
\text { at high temperatures, oxidation of } \\
\text { magnetite nanoparticles }\end{array}$ & [180] & $20-100$ & $<10 \mathrm{mg} \mathrm{Fe} / \mathrm{kg}$ & [181] & Citrin & $175 \mu \mathrm{g} / \mathrm{mg}$ & [109] \\
\hline $\begin{array}{l}\text { Montmorillonite } \\
\text { nanocomposite }\end{array}$ & $\begin{array}{l}\text { hot intercalation technique, in situ } \\
\text { polymerization, solution induced } \\
\text { intercalation } 10 \text {, melt processing }\end{array}$ & [184] & $1-5$ & $1000 \mathrm{mg} / \mathrm{kg}$ & [185] & AFL & $67 \mu \mathrm{g} / \mathrm{mg}$ & [119] \\
\hline $\begin{array}{c}\text { Modified } \\
\text { halloysite nanotubes }\end{array}$ & naturally occuring & [121] & $<1$ & $10 \mathrm{mg} / \mathrm{mL}$ & [119] & ZEA & $1000 \mu \mathrm{g} / \mathrm{mg}$ & [136] \\
\hline
\end{tabular}




\section{Conclusions}

In this review, we summarized the current findings of mycotoxins and their elimination by nanoparticles. Many researchers see the application potential of nanomaterials in the field of biosensors for mycotoxin detection rather than elimination. Although the exceptional properties of nanomaterials have obliged the development of this field of knowledge, the combination of knowledge of disciplines from toxicology, nanotechnology, and agricultural practices is on the rise. These findings further support the idea of the one nanoparticle which could be employed for mycotoxin detection as well as elimination and could serve as a nanocage for nutrition delivery. Further research should be done to investigate the detailed toxicity and efficiency testing as is also required in other nanotechnology disciplines. The conclusion of this review suggests that nanomaterials have interesting adsorption properties, which make them promising for mycotoxin elimination.

Author Contributions: Conceptualization, P.H.; Resources, S.S., P.H.; Writing-Original Draft Preparation, P.H.; S.S.; D.B.; Writing-Review and Editing, J.S.; S.S.; Visualization, D.B.; Supervision, J.S.; Project Administration, P.H.; Funding Acquisition, P.H.

Funding: This work was supported by the TACR ZETA under grant TJ01000116; IGA of Mendel University under grant IGA-2018-tym001.

Conflicts of Interest: The authors declare that they have no conflict of interest.

\section{References}

1. Edwards, S.G. Influence of agricultural practices on fusarium infection of cereals and subsequent contamination of grain by trichothecene mycotoxins. Toxicol. Lett. 2004, 153, 29-35. [CrossRef] [PubMed]

2. Simpson, D.R.; Weston, G.E.; Turner, J.A.; Jennings, P.; Nicholson, P. Differential control of head blight pathogens of wheat by fungicides and consequences for mycotoxin contamination of grain. Eur. J. Plant Pathol. 2001, 107, 421-431. [CrossRef]

3. Cunha, S.C.; Sa, S.V.M.; Fernandes, J.O. Multiple mycotoxin analysis in nut products: Occurrence and risk characterization. Food Chem. Toxicol. 2018, 114, 260-269. [CrossRef] [PubMed]

4. Santini, A.; Meca, G.; Uhlig, S.; Ritieni, A. Fusaproliferin, beauvericin and enniatins: Occurrence in food-A review. World Mycotoxin J. 2012, 5, 71-81. [CrossRef]

5. Jestoi, M. Emerging fusarium-mycotoxins fusaproliferin, beauvericin, enniatins, and moniliformin-A review. Crit. Rev. Food Sci. Nutr. 2008, 48, 21-49. [CrossRef] [PubMed]

6. Marin, S.; Ramos, A.J.; Cano-Sancho, G.; Sanchis, V. Mycotoxins: Occurrence, toxicology, and exposure assessment. Food Chem. Toxicol. 2013, 60, 218-237. [CrossRef] [PubMed]

7. Madalena, M.; Sobral, C.; Faria, M.A.; Cunha, S.C.; Ferreira, I. Toxicological interactions between mycotoxins from ubiquitous fungi: Impact on hepatic and intestinal human epithelial cells. Chemosphere 2018, 202, 538-548.

8. Dellafiora, L.; Dall'Asta, C.; Galaverna, G. Toxicodynamics of mycotoxins in the framework of food risk assessmentan in silico perspective. Toxins 2018, 10, 52. [CrossRef] [PubMed]

9. Freire, L.; Sant'Ana, A.S. Modified mycotoxins: An updated review on their formation, detection, occurrence, and toxic effects. Food Chem. Toxicol. 2018, 111, 189-205. [CrossRef] [PubMed]

10. Berthiller, F.; Maragos, C.M.; Dall'Asta, C. Introduction to masked mycotoxins. In Masked Mycotoxins in Food: Formation, Occurrence and Toxicological Relevance; DallAsta, C., Berthiller, F., Eds.; Royal Society of Chemistry: London, UK, 2016; Volume 24, pp. 1-13.

11. Osweiler, G.D. Mycotoxins-Contemporary issues of food animal health and productivity. Vet. Clin. N. Am. Food Anim. Pract. 2000, 16, 511-530. [CrossRef]

12. Dell'Orto, V.; Baldi, G.; Cheli, F. Mycotoxins in silage: Checkpoints for effective management and control. World Mycotoxin J. 2015, 8, 603-617. [CrossRef]

13. Cheat, S.; Oswald, I.P.; Kolf-Clauw, M. Mycotoxin Outbreak in Animal Feed; CRC Press-Taylor \& Francis Group: Boca Raton, FL, USA, 2016; pp. 257-286.

14. Rodrigues, I. A review on the effects of mycotoxins in dairy ruminants. Anim. Prod. Sci. 2014, 54, 1155-1165. [CrossRef] 
15. Krstanovic, V.; Sarkanj, B.; Velic, N.; Mastanjevic, K.; Santek, B. Mycotoxins in malting and brewing by-products used for animal feed. J. Biotechnol. 2017, 256, S68-S69. [CrossRef]

16. Aslam, N.; Rodrigues, I.; McGill, D.M.; Warriach, H.M.; Cowling, A.; Haque, A.; Wynn, P.C. Transfer of aflatoxins from naturally contaminated feed to milk of Nili-Ravi buffaloes fed a mycotoxin binder. Anim. Prod. Sci. 2016, 56, 1637-1642. [CrossRef]

17. Dal Pozzo, M.; Viegas, J.; Kozloski, G.V.; Stefanello, C.M.; da Silveira, A.M.; Bayer, C.; Santurio, J.M. The effect of mycotoxins adsorbents beta glucans or montmorillonite on bovine ruminal fermentation in vitro. Acta Sci. Vet. 2016, 44, 6. [CrossRef]

18. Bhatti, S.A.; Khan, M.Z.; Ul Hassan, Z.; Saleemi, M.K.; Saqib, M.; Khatoon, A.; Akhter, M. Comparative efficacy of bentonite clay, activated charcoal and trichosporon mycotoxinivorans in regulating the feed-to-tissue transfer of mycotoxins. J. Sci. Food Agric. 2018, 98, 884-890. [CrossRef] [PubMed]

19. Brown, K.A.; Mays, T.; Romoser, A.; Marroquin-Cardona, A.; Mitchell, N.J.; Elmore, S.E.; Phillips, T.D. Modified hydra bioassay to evaluate the toxicity of multiple mycotoxins and predict the detoxification efficacy of a clay-based sorbent. J. Appl. Toxicol. 2014, 34, 40-48. [CrossRef] [PubMed]

20. Campagnollo, F.B.; Franco, L.T.; Rottinghaus, G.E.; Kobashigawa, E.; Ledoux, D.R.; Dakovic, A.; Oliveira, C.A.F. In vitro evaluation of the ability of beer fermentation residue containing saccharomyces cerevisiae to bind mycotoxins. Food Res. Int. 2015, 77, 643-648. [CrossRef]

21. Mendieta, C.R.; Gomez, G.V.; Del Rio, J.C.G.; Cuevas, A.C.; Arce, J.M.; Avila, E.G. Effect of the addition of saccharomyces cerevisiae yeast cell walls to diets with mycotoxins on the performance and immune responses of broilers. J. Poult. Sci. 2018, 55, 38-46. [CrossRef]

22. Nathanail, A.V.; Gibson, B.; Han, L.; Peltonen, K.; Ollilainen, V.; Jestoi, M.; Laitila, A. The lager yeast saccharomyces pastorianus removes and transforms fusarium trichothecene mycotoxins during fermentation of brewer's wort. Food Chem. 2016, 203, 448-455. [CrossRef] [PubMed]

23. Singh, A.; Prasad, S.M. Nanotechnology and its role in agro-ecosystem: A strategic perspective. Int. J. Environ. Sci. Technol. 2017, 14, 2277-2300. [CrossRef]

24. Chen, H.D.; Seiber, J.N.; Hotze, M. Acs select on nanotechnology in food and agriculture: A perspective on implications and applications. J. Agric. Food Chem. 2014, 62, 1209-1212. [CrossRef] [PubMed]

25. Pfeiffer, C.; Rehbock, C.; Huhn, D.; Carrillo-Carrion, C.; de Aberasturi, D.J.; Merk, V.; Barcikowski, S.; Parak, W.J. Interaction of colloidal nanoparticles with their local environment: The (ionic) nanoenvironment around nanoparticles is different from bulk and determines the physico-chemical properties of the nanoparticles. J. R. Soc. Interface 2014, 11, 20130931. [CrossRef] [PubMed]

26. Kaushik, A.; Solanki, P.R.; Ansari, A.A.; Ahmad, S.; Malhotra, B.D. A nanostructured cerium oxide film-based immunosensor for mycotoxin detection. Nanotechnology 2009, 20, 055105. [CrossRef] [PubMed]

27. Anfossi, L.; Giovannoli, C.; Baggiani, C. Mycotoxin detection. Curr. Opin. Biotechnol. 2016, 37, $120-126$. [CrossRef] [PubMed]

28. Chauhan, R.; Singh, J.; Sachdev, T.; Basu, T.; Malhotra, B.D. Recent advances in mycotoxins detection. Biosens. Bioelectron. 2016, 81, 532-545. [CrossRef] [PubMed]

29. Berthiller, F.; Brera, C.; Iha, M.H.; Krska, R.; Lattanzio, V.M.T.; MacDonald, S.; Malone, R.J.; Maragos, C.; Solfrizzo, M.; Stranska-Zachariasova, M.; et al. Developments in mycotoxin analysis: An update for 2015-2016. World Mycotoxin J. 2017, 10, 5-29. [CrossRef]

30. Guo, L.J.; Feng, J.S.; Fang, Z.C.; Xu, J.; Lu, X.N. Application of microfluidic "lab-on-a-chip" for the detection of mycotoxins in foods. Trends Food Sci. Technol. 2015, 46, 252-263. [CrossRef]

31. Selvaraj, J.N.; Zhou, L.; Wang, Y.; Zhao, Y.J.; Xing, F.G.; Dai, X.F.; Liu, Y. Mycotoxin detection-Recent trends at global level. J. Integr. Agric. 2015, 14, 2265-2281. [CrossRef]

32. Sadhasivam, S.; Britzi, M.; Zakin, V.; Kostyukovsky, M.; Trostanetsky, A.; Quinn, E.; Sionov, E. Rapid detection and identification of mycotoxigenic fungi and mycotoxins in stored wheat grain. Toxins 2017, 9, 302. [CrossRef] [PubMed]

33. Rai, M.; Jogee, P.S.; Ingle, A.P. Emerging nanotechnology for detection of mycotoxins in food and feed. Int. J. Food Sci. Nutr. 2015, 66, 363-370. [CrossRef] [PubMed]

34. Rhouati, A.; Bulbul, G.; Latif, U.; Hayat, A.; Li, Z.H.; Marty, J.L. Nano-aptasensing in mycotoxin analysis: Recent updates and progress. Toxins 2017, 9, 349. [CrossRef] [PubMed] 
35. Gontero, D.; Lessard-Viger, M.; Brouard, D.; Bracamonte, A.G.; Boudreau, D.; Veglia, A.V. Smart multifunctional nanoparticles design as sensors and drug delivery systems based on supramolecular chemistry. Microchem. J. 2017, 130, 316-328. [CrossRef]

36. Xie, Y.J.; Yang, Y.; Kong, W.J.; Yang, S.H.; Yang, M.H. Application of nanoparticle probe-based lateral flow immunochromatographic assay in mycotoxins detection. Chin. J. Anal. Chem. 2015, 43, 617-628. [CrossRef]

37. Solanki, P.R.; Singh, J.; Rupavali, B.; Tiwari, S.; Malhotra, B.D. Bismuth oxide nanorods based immunosensor for mycotoxin detection. Mater. Sci. Eng. C Mater. Biol. Appl. 2017, 70, 564-571. [CrossRef] [PubMed]

38. Zhang, W.J.; Li, G.X. Third-generation biosensors based on the direct electron transfer of proteins. Anal. Sci. 2004, 20, 603-609. [CrossRef] [PubMed]

39. Petrakova, A.V.; Urusov, A.E.; Zherdev, A.V.; Liu, L.; Xu, C.; Dzantiev, B.B. Application of magnetite nanoparticles for the development of highly sensitive immunochromatographic test systems for mycotoxin detection. Appl. Biochem. Microbiol. 2017, 53, 470-475. [CrossRef]

40. Lv, X.; Li, Y.; Yan, T.; Pang, X.; Cao, W.; Du, B.; Wu, D.; Wei, Q. Electrochemiluminescence modified electrodes based on RuSi@Ru(bpy) ${ }_{3}{ }^{2+}$ loaded with gold functioned nanoporous $\mathrm{CO} / \mathrm{Co}_{3} \mathrm{O}_{4}$ for detection of mycotoxin deoxynivalenol. Biosens. Bioelectron. 2015, 70, 28-33. [CrossRef] [PubMed]

41. Zhao, Y.; Yang, Y.; Luo, Y.; Yang, X.; Li, M.; Song, Q. Double detection of mycotoxins based on sers labels embedded Ag@Au core-shell nanoparticles. Acs Appl. Mater. Interfaces 2015, 7, 21780-21786. [CrossRef] [PubMed]

42. Sun, Y.; Xing, G.; Yang, J.; Wang, F.; Deng, R.; Zhang, G.; Hu, X.; Zhang, Y. Development of an immunochromatographic test strip for simultaneous qualitative and quantitative detection of ochratoxin a and zearalenone in cereal. J. Sci. Food Agric. 2016, 96, 3673-3678. [CrossRef] [PubMed]

43. Kong, D.; Liu, L.; Song, S.; Suryoprabowo, S.; Li, A.; Kuang, H.; Wang, L.; Xu, C. A gold nanoparticle-based semi-quantitative and quantitative ultrasensitive paper sensor for the detection of twenty mycotoxins. Nanoscale 2016, 8, 5245-5253. [CrossRef] [PubMed]

44. Berthiller, F.; Crews, C.; Dall'Asta, C.; De Saeger, S.; Haesaert, G.; Karlovsky, P.; Oswald, I.P.; Seefelder, W.; Speijers, G.; Stroka, J. Masked mycotoxins: A review. Mol. Nutr. Food Res. 2013, 57, 165-186. [CrossRef] [PubMed]

45. Goryacheva, I.Y.; De Saeger, S. Immunochemical detection of masked mycotoxins: A short review. World Mycotoxin J. 2012, 5, 281-287. [CrossRef]

46. Huybrechts, B.; Martins, J.C.; Debongnie, P.; Uhlig, S.; Callebaut, A. Fast and sensitive LC-MS/MS method measuring human mycotoxin exposure using biomarkers in urine. Arch. Toxicol. 2015, 89, 1993-2005. [CrossRef] [PubMed]

47. Nakagawa, H.; Ohmichi, K.; Sakamoto, S.; Sago, Y.; Kushiro, M.; Nagashima, H.; Yoshida, M.; Nakajima, T. Detection of a new fusarium masked mycotoxin in wheat grain by high-resolution LC-Orbitrap ${ }^{\mathrm{TM}}$ MS. Food Addit. Contam. Part A Chem. Anal. Control Expo. Risk Assess. 2011, 28, 1447-1456. [CrossRef] [PubMed]

48. Aqai, P.; Peters, J.; Gerssen, A.; Haasnoot, W.; Nielen, M.W.F. Immunomagnetic microbeads for screening with flow cytometry and identification with nano-liquid chromatography mass spectrometry of ochratoxins in wheat and cereal. Anal. Bioanal. Chem. 2011, 400, 3085-3096. [CrossRef] [PubMed]

49. Sureka, S.; Chalcravorty, A.; Holmes, E.C.; Spassibojko, O.; Bhatt, N.; Wu, D.L.; Turgeon, B.G. Standardization of functional reporter and antibiotic resistance cassettes to facilitate the genetic engineering of filamentous fungi. ACS Synth. Biol. 2014, 3, 960-962. [CrossRef] [PubMed]

50. Niemirowicz, K.; Durnas, B.; Piktel, E.; Bucki, R. Development of antifungal therapies using nanomaterials. Nanomedicine 2017, 12, 1891-1905. [CrossRef] [PubMed]

51. Roque, L.; Molpeceres, J.; Reis, C.; Rijo, P.; Reis, C.P. Past, recent progresses and future perspectives of nanotechnology applied to antifungal agents. Curr. Drug Metab. 2017, 18, 280-290. [CrossRef] [PubMed]

52. Niemirowicz, K.; Bucki, R. Enhancing the fungicidal activity of antibiotics: Are magnetic nanoparticles the key? Nanomedicine 2017, 12, 1747-1749. [CrossRef] [PubMed]

53. Soliman, G.M. Nanoparticles as safe and effective delivery systems of antifungal agents: Achievements and challenges. Int. J. Pharm. 2017, 523, 15-32. [CrossRef] [PubMed]

54. Voltan, A.R.; Quindos, G.; Alarcon, K.P.M.; Fusco-Almeida, A.M.; Mendes-Giannini, M.J.S.; Chorilli, M. Fungal diseases: Could nanostructured drug delivery systems be a novel paradigm for therapy? Int. J. Nanomed. 2016, 11, 3715-3730. [CrossRef] [PubMed] 
55. Adelere, I.A.; Lateef, A. A novel approach to the green synthesis of metallic nanoparticles: The use of agro-wastes, enzymes, and pigments. Nanotechnol. Rev. 2016, 5, 567-587. [CrossRef]

56. Gupta, D.; Chauhan, P. Fungicidal activity of silver nanoparticles against Alternaria brassicicola. In $2 n d$ International Conference on Emerging Technologies: Micro to Nano 2015; Sharma, N.N., Gaol, F.L., Akhtar, J., Eds.; AIP Publishing: Melville, NY, USA, 2016; Volume 1724.

57. Abdel-Hafez, S.I.I.; Nafady, N.A.; Abdel-Rahim, I.R.; Shaltout, A.M.; Daros, J.A.; Mohamed, M.A. Assessment of protein silver nanoparticles toxicity against pathogenic Alternaria solani. 3 Biotech 2016, 6, 199. [CrossRef] [PubMed]

58. Majumder, S.; Shakil, N.A.; Kumar, J.; Banerjee, T.; Sinha, P.; Singh, B.B.; Garg, P. Eco-friendly peg-based controlled release nano-formulations of mancozeb: Synthesis and bioefficacy evaluation against phytopathogenic fungi alternaria solani and sclerotium rolfsii. J. Environ. Sci. Health Part B Pest. Contam. Agric. Wastes 2016, 51, 873-880. [CrossRef] [PubMed]

59. Khalili, S.T.; Mohsenifar, A.; Beyki, M.; Zhaveh, S.; Rahmani-Cherati, T.; Abdollahi, A.; Bayat, M.; Tabatabaei, M. Encapsulation of thyme essential oils in chitosan-benzoic acid nanogel with enhanced antimicrobial activity against aspergillus flavus. LWT-Food Sci. Technol. 2015, 60, 502-508. [CrossRef]

60. Beyki, M.; Zhaveh, S.; Khalili, S.T.; Rahmani-Cherati, T.; Abollahi, A.; Bayat, M.; Tabatabaei, M.; Mohsenifar, A. Encapsulation of mentha piperita essential oils in chitosan-cinnamic acid nanogel with enhanced antimicrobial activity against aspergillus flavus. Ind. Crops Prod. 2014, 54, 310-319. [CrossRef]

61. Zhaveh, S.; Mohsenifar, A.; Beiki, M.; Khalili, S.T.; Abdollahi, A.; Rahmani-Cherati, T.; Tabatabaei, M. Encapsulation of cuminum cyminum essential oils in chitosan-caffeic acid nanogel with enhanced antimicrobial activity against aspergillus flavus. Ind. Crops Prod. 2015, 69, 251-256. [CrossRef]

62. Li, H.B.; Shen, Q.S.; Zhou, W.; Mo, H.Z.; Pan, D.D.; Hu, L.B. Nanocapsular dispersion of cinnamaldehyde for enhanced inhibitory activity against aflatoxin production by aspergillus flavus. Molecules 2015, 20, 6022-6032. [CrossRef] [PubMed]

63. Zhao, J.; Wang, L.; Xu, D.; Lu, Z.S. Involvement of ros in nanosilver-caused suppression of aflatoxin production from aspergillus flavus. RSC Adv. 2017, 7, 23021-23026. [CrossRef]

64. Babaei, E.; Dehnad, A.; Hajizadeh, N.; Valizadeh, H.; Reihani, S.F.S. A study on inhibitory effects of titanium dioxide nanoparticles and its photocatalytic type on Staphylococcus aureus, Escherichia coli and Aspergillus flavus. Appl. Food Biotechnol. 2016, 3, 115-123.

65. Yu, K.P.; Huang, Y.T.; Yang, S.C. The antifungal efficacy of nano-metals supported $\mathrm{TiO}_{2}$ and ozone on the resistant aspergillus niger spore. J. Hazard. Mater. 2013, 261, 155-162. [CrossRef] [PubMed]

66. Pinto, R.J.B.; Almeida, A.; Fernandes, S.C.M.; Freire, C.S.R.; Silvestre, A.J.D.; Neto, C.P.; Trindade, T. Antifungal activity of transparent nanocomposite thin films of pullulan and silver against aspergillus niger. Colloid Surf. B Biointerfaces 2013, 103, 143-148. [CrossRef] [PubMed]

67. Mitra, C.; Gummadidala, P.M.; Afshinnia, K.; Merrifield, R.C.; Baalousha, M.; Lead, J.R.; Chanda, A. Citrate-coated silver nanoparticles growth-independently inhibit aflatoxin synthesis in aspergillus parasiticus. Environ. Sci. Technol. 2017, 51, 8085-8093. [CrossRef] [PubMed]

68. Mousavi, S.A.A.; Pourtalebi, S. Inhibitory effects of silver nanoparticles on growth and aflatoxin B-1 production by aspergillus parasiticus. Iran. J. Med. Sci. 2015, 40, 501-506.

69. Rashed, A.-O.M.; Mohamed, A.-E.-A.A.R.; Abobakr, M.M. Wheat protection from root rot caused by fusarium culmorum using silver nanoparticles. J. Chem. Soc. Pak. 2016, 38, 898-903.

70. Kheiri, A.; Moosawi Jorf, S.A.; Malihipour, A.; Saremi, H.; Nikkhah, M. Synthesis and characterization of chitosan nanoparticles and their effect on fusarium head blight and oxidative activity in wheat. Int. J. Biol. Macromol. 2017, 102, 526-538. [CrossRef] [PubMed]

71. Dananjaya, S.H.S.; Erandani, W.; Kim, C.H.; Nikapitiya, C.; Lee, J.; De Zoysa, M. Comparative study on antifungal activities of chitosan nanoparticles and chitosan silver nano composites against fusarium oxysporum species complex. Int. J. Biol. Macromol. 2017, 105, 478-488. [CrossRef] [PubMed]

72. Shenashen, M.; Derbalah, A.; Hamza, A.; Mohamed, A.; El Safty, S. Antifungal activity of fabricated mesoporous alumina nanoparticles against root rot disease of tomato caused by fusarium oxysporium. Pest Manag. Sci. 2017, 73, 1121-1126. [CrossRef] [PubMed]

73. Boxi, S.S.; Mukherjee, K.; Paria, S. Ag doped hollow $\mathrm{TiO}_{2}$ nanoparticles as an effective green fungicide against fusarium solani and venturia inaequalis phytopathogens. Nanotechnology 2016, 27, 085103. [CrossRef] [PubMed] 
74. He, L.L.; Liu, Y.; Mustapha, A.; Lin, M.S. Antifungal activity of zinc oxide nanoparticles against botrytis cinerea and penicillium expansum. Microbiol. Res. 2011, 166, 207-215. [CrossRef] [PubMed]

75. Khamis, Y.; Hashim, A.F.; Margarita, R.; Alghuthaymi, M.A.; Abd-Elsalam, K.A. Fungicidal efficacy of chemically-produced copper nanoparticles against penicillium digitatum and fusarium solani on citrus fruit. Philipp. Agric. Sci. 2017, 100, 69-78.

76. Kotzybik, K.; Graf, V.; Kugler, L.; Stoll, D.A.; Greiner, R.; Geisen, R.; Schmidt-Heydt, M. Influence of different nanomaterials on growth and mycotoxin production of penicillium verrucosum. PLoS ONE 2016, 11, e0150855. [CrossRef] [PubMed]

77. Zeng, X.L.; Zhang, F.Q.; He, N.Y.; Zhang, B.Y.; Liu, X.Y.; Li, X.L. Zno nanoparticles of different shapes and their antimycotic property against penicillium and mucor. Nanosci. Nanotechnol. Lett. 2016, 8, 688-694. [CrossRef]

78. Medda, S.; Hajra, A.; Dey, U.; Bose, P.; Mondal, N.K. Biosynthesis of silver nanoparticles from Aloe vera leaf extract and antifungal activity against Rhizopus sp. and Aspergillus sp. Appl. Nanosci. 2015, 5, 875-880. [CrossRef]

79. Ammar, H.A.M.; El-Desouky, T.A. Green synthesis of nanosilver particles by aspergillus terreus HA1N and penicillium expansum $\mathrm{HA} 2 \mathrm{~N}$ and its antifungal activity against mycotoxigenic fungi. J. Appl. Microbiol. 2016, 121, 89-100. [CrossRef] [PubMed]

80. Devipriya, D.; Roopan, S.M. Cissus quadrangularis mediated ecofriendly synthesis of copper oxide nanoparticles and its antifungal studies against aspergillus niger, aspergillus flavus. Mater. Sci. Eng. C Mater. Biol. Appl. 2017, 80, 38-44. [CrossRef] [PubMed]

81. Yassin, M.A.; El-Samawaty, A.M.A.; Dawoud, T.M.; Abd-Elkader, O.H.; Al Maary, K.S.; Hatamleh, A.A.; Elgorban, A.M. Characterization and anti-aspergillus flavus impact of nanoparticles synthesized by penicillium citrinum. Saudi J. Biol. Sci. 2017, 24, 1243-1248. [CrossRef] [PubMed]

82. Shakibaie, M.; Mohazab, N.S.; Mousavi, S.A.A. Antifungal activity of selenium nanoparticles synthesized by bacillus species Msh-1 against aspergillus fumigatus and candida albicans. Jundishapur J. Microbiol. 2015, 8, e26381. [CrossRef] [PubMed]

83. Xue, B.J.; He, D.; Gao, S.; Wang, D.Y.; Yokoyama, K.; Wang, L. Biosynthesis of silver nanoparticles by the fungus arthroderma fulvum and its antifungal activity against genera of candida, aspergillus and fusarium. Int. J. Nanomed. 2016, 11, 1899-1906.

84. Madbouly, A.K.; Abdel-Aziz, M.S.; Abdel-Wahhab, M.A. Biosynthesis of nanosilver using chaetomium globosum and its application to control fusarium wilt of tomato in the greenhouse. IET Nanobiotechnol. 2017, 11, 702-708. [CrossRef]

85. Pietrzak, K.; Twaruzek, M.; Czyzowska, A.; Kosicki, R.; Gutarowska, B. Influence of silver nanoparticles on metabolism and toxicity of moulds. Acta Biochim. Pol. 2015, 62, 851-857. [CrossRef] [PubMed]

86. Lara, H.H.; Romero-Urbina, D.G.; Pierce, C.; Lopez-Ribot, J.L.; Arellano-Jimenez, M.J.; Jose-Yacaman, M. Effect of silver nanoparticles on candida albicans biofilms: An ultrastructural study. J. Nanobiotechnol. 2015, 13, 91. [CrossRef] [PubMed]

87. Tang, Z.Y.; Kotov, N.A. One-dimensional assemblies of nanoparticles: Preparation, properties, and promise. Adv. Mater. 2005, 17, 951-962. [CrossRef]

88. Stroka, J.; Maragos, C.M. Challenges in the analysis of multiple mycotoxins. World Mycotoxin J. 2016, 9 , 847-861. [CrossRef]

89. Chemical and physical characteristics of the principal mycotoxins. IARC Sci. Public 2012, 158, 31-38.

90. Gibson, N.; Shenderova, O.; Luo, T.J.M.; Moseenkov, S.; Bondar, V.; Puzyr, A.; Purtov, K.; Fitzgerald, Z.; Brenner, D.W. Colloidal stability of modified nanodiamond particles. Diam. Relat. Mater. 2009, 18, 620-626. [CrossRef]

91. Chen, W.; Duan, L.; Zhu, D.Q. Adsorption of polar and nonpolar organic chemicals to carbon nanotubes. Environ. Sci. Technol. 2007, 41, 8295-8300. [CrossRef] [PubMed]

92. Kovac, T.; Sarkanj, B.; Klapec, T.; Borisev, I.; Kovac, M.; Nevistic, A.; Strelec, I. Fullerol C ${ }_{60}(\mathrm{OH})_{24}$ nanoparticles and mycotoxigenic fungi: A preliminary investigation into modulation of mycotoxin production. Environ. Sci. Pollut. Res. 2017, 24, 16673-16681. [CrossRef] [PubMed]

93. Aoshima, H.; Kokubo, K.; Shirakawa, S.; Ito, M.; Yamana, S.; Oshima, T. Antimicrobial activity of fullerenes and their hydroxylated derivatives. Biocontrol Sci. 2009, 14, 69-72. [CrossRef] [PubMed] 
94. Puzyr, A.P.; Purtov, K.V.; Shenderova, O.A.; Luo, M.; Brenner, D.W.; Bondar, V.S. The adsorption of aflatoxin B1 by detonation-synthesis nanodiamonds. Dokl. Biochem. Biophys. 2007, 417, 299-301. [CrossRef] [PubMed]

95. Gibson, N.M.; Luo, T.J.M.; Brenner, D.W.; Shenderova, O. Immobilization of mycotoxins on modified nanodiamond substrates. Biointerphases 2011, 6, 210-217. [CrossRef] [PubMed]

96. Golokhvast, K.S.; Chaika, V.V.; Kuznetsov, L.V.; Elumeeva, K.V.; Kusaikin, M.I.; Zakharenko, A.M.; Kiselev, N.N.; Panichev, A.M.; Reva, G.V.; Usov, V.V.; et al. Effects of multiwalled carbon nanotubes received orally during 6 days on the gastrointestinal tract. Bull. Exp. Biol. Med. 2013, 155, 788-792. [CrossRef] [PubMed]

97. Boczkowski, J.; Lanone, S. Potential uses of carbon nanotubes in the medical field: How worried should patients be? Nanomedicine 2007, 2, 407-410. [CrossRef] [PubMed]

98. Han, Z.; Jiang, K.; Fan, Z.; Diana Di Mavungu, J.; Dong, M.; Guo, W.; Fan, K.; Campbell, K.; Zhao, Z.; Wu, Y. Multi-walled carbon nanotubes-based magnetic solid-phase extraction for the determination of zearalenone and its derivatives in maize by ultra-high performance liquid chromatography-tandem mass spectrometry. Food Control 2017, 79, 177-184. [CrossRef]

99. Ying, Y.-F.; Wu, Y.-L.; Wen, Y.; Yang, T.; Xu, X.-Q.; Wang, Y.-Z. Simultaneous determination of six resorcylic acid lactones in feed using liquid chromatography-tandem mass spectrometry and multi-walled carbon nanotubes as a dispersive solid phase extraction sorbent. J. Chromatogr. A 2013, 1307, 41-48. [CrossRef] [PubMed]

100. Moreno, V.; Zougagh, M.; Rios, A. Hybrid nanoparticles based on magnetic multiwalled carbon nanotube-nanoC ${ }_{18} \mathrm{SiO}_{2}$ composites for solid phase extraction of mycotoxins prior to their determination by LC-MS. Microchim. Acta 2016, 183, 871-880. [CrossRef]

101. Dong, M.; Si, W.; Wang, W.; Bai, B.; Nie, D.; Song, W.; Zhao, Z.; Guo, Y.; Han, Z. Determination of type a trichothecenes in coix seed by magnetic solid-phase extraction based on magnetic multi-walled carbon nanotubes coupled with ultra-high performance liquid chromatography-tandem mass spectrometry. Anal. Bioanal. Chem. 2016, 408, 6823-6831. [CrossRef] [PubMed]

102. Jiang, K.; Huang, P.; Luan, L.; Fan, K.; Guo, W.; Zhao, Z.; Wu, Y.; Han, Z. Iron (II, III) oxide/multi-walled carbon nanotube composite as solid-phase extraction sorbent followed by ultra-high performance liquid chromatography tandem mass spectrometry for simultaneous determination of zearalenone and type a trichothecenes in salviae miltiorrhizae radix et rhizoma (danshen). J. Chromatogr. A 2017, 1482, 1-10. [PubMed]

103. Dong, M.; Si, W.; Jiang, K.; Nie, D.; Wu, Y.; Zhao, Z.; De Saeger, S.; Han, Z. Multi-walled carbon nanotubes as solid-phase extraction sorbents for simultaneous determination of type a trichothecenes in maize, wheat and rice by ultra-high performance liquid chromatography-tandem mass spectrometry. J. Chromatogr. A 2015, 1423, 177-182. [CrossRef] [PubMed]

104. Singh, C.; Srivastava, S.; Ali, M.A.; Gupta, T.K.; Sumana, G.; Srivastava, A.; Mathur, R.B.; Malhotra, B.D. Carboxylated multiwalled carbon nanotubes based biosensor for aflatoxin detection. Sens. Actuators B Chem. 2013, 185, 258-264. [CrossRef]

105. Pirouz, A.A.; Selamat, J.; Iqbal, S.Z.; Mirhosseini, H.; Karjiban, R.A.; Bakar, F.A. The use of innovative and efficient nanocomposite (magnetic graphene oxide) for the reduction on of fusarium mycotoxins in palm kernel cake. Sci. Rep. 2017, 7, 12453. [CrossRef] [PubMed]

106. Magro, M.; Moritz, D.E.; Bonaiuto, E.; Baratella, D.; Terzo, M.; Jakubec, P.; Malina, O.; Cepe, K.; Falcao de Aragao, G.M.; Zboril, R.; et al. Citrinin mycotoxin recognition and removal by naked magnetic nanoparticles. Food Chem. 2016, 203, 505-512. [CrossRef] [PubMed]

107. Khajarern, J.M.; Khajarern, S.; Moon, T.H.; Lee, J.H. Effects of dietary supplementation of fermented chitin-chitosan (fermkit) on toxicity of mycotoxin in ducks. Asian-Australas. J. Anim. Sci. 2003, 16, 706-713. [CrossRef]

108. Huang, J.; Huang, Z.; Kang, Y.; Wang, A.; Zong, L. Mycotoxin Adsorbent Preparation Used for Removing Feed Mycotoxin Zearalenone and Reducing Diarrhea, and Used as Antibacterial, Involves Dissolving Chitosan in Organic Acid Solution, and then Adding Rectorite is Added to Solution. CN Patent CN103831088-A, 4 June 2014; CN103831088-B, 27 January 2016.

109. Desai, K.G.H. Chitosan nanoparticles prepared by ionotropic gelation: An overview of recent advances. Crit. Rev. Ther. Drug Carrier Syst. 2016, 33, 107-158. [CrossRef] [PubMed] 
110. Huang, Y.; Lapitsky, Y. On the kinetics of chitosan/tripolyphosphate micro- and nanogel aggregation and their effects on particle polydispersity. J. Colloid Interface Sci. 2017, 486, 27-37. [CrossRef] [PubMed]

111. Sacco, P.; Paoletti, S.; Cok, M.; Asaro, F.; Abrami, M.; Grassi, M.; Donati, I. Insight into the ionotropic gelation of chitosan using tripolyphosphate and pyrophosphate as cross-linkers. Int. J. Biol. Macromol. 2016, 92, 476-483. [CrossRef] [PubMed]

112. Graham, L.M.; Nguyen, T.M.; Lee, S.B. Nanodetoxification: Emerging role of nanomaterials in drug intoxication treatment. Nanomedicine 2011, 6, 921-928. [CrossRef] [PubMed]

113. Zhao, Z.; Liu, N.; Yang, L.; Wang, J.; Song, S.; Nie, D.; Yang, X.; Hou, J.; Wu, A. Cross-linked chitosan polymers as generic adsorbents for simultaneous adsorption of multiple mycotoxins. Food Control 2015, 57, 362-369. [CrossRef]

114. Luo, Y.; Zhou, Z.; Yue, T. Synthesis and characterization of nontoxic chitosan-coated $\mathrm{Fe}_{3} \mathrm{O}_{4}$ particles for patulin adsorption in a juice-pH simulation aqueous. Food Chem. 2017, 221, 317-323. [CrossRef] [PubMed]

115. Swain, P.S.; Rao, S.B.N.; Rajendran, D.; Dominic, G.; Selvaraju, S. Nano zinc, an alternative to conventional zinc as animal feed supplement: A review. Anim. Nutr. 2016, 2, 134-141. [CrossRef] [PubMed]

116. Shi, Y.H.; Xu, Z.R.; Feng, J.L.; Wang, C.Z. Efficacy of modified montmorillonite nanocomposite to reduce the toxicity of aflatoxin in broiler chicks. Anim. Feed Sci. Technol. 2006, 129, 138-148. [CrossRef]

117. Al-Shemmari, F.H.J.; Rabah, A.A.; Al-Mulla, E.A.J.; Abd Alrahman, N.O.M. Preparation and characterization of natural rubber latex/modified montmorillonite clay nano-composite. Res. Chem. Intermed. 2013, 39, 4293-4301. [CrossRef]

118. Yuan, P.; Tan, D.Y.; Annabi-Bergaya, F. Properties and applications of halloysite nanotubes: Recent research advances and future prospects. Appl. Clay Sci. 2015, 112, 75-93. [CrossRef]

119. Lvov, Y.; Wang, W.C.; Zhang, L.Q.; Fakhrullin, R. Halloysite clay nanotubes for loading and sustained release of functional compounds. Adv. Mater. 2016, 28, 1227-1250. [CrossRef] [PubMed]

120. Lun, H.L.; Ouyang, J.; Yang, H.M. Natural halloysite nanotubes modified as an aspirin carrier. RSC Adv. 2014, 4, 44197-44202. [CrossRef]

121. Patel, S.; Jammalamadaka, U.; Sun, L.; Tappa, K.; Mills, D.K. Sustained release of antibacterial agents from doped halloysite nanotubes. Bioengineering 2016, 3, 1. [CrossRef] [PubMed]

122. Hanif, M.; Jabbar, F.; Sharif, S.; Abbas, G.; Farooq, A.; Aziz, M. Halloysite nanotubes as a new drug-delivery system: A review. Clay Miner. 2016, 51, 469-477. [CrossRef]

123. Sun, L.; Mills, D.K.; IEEE. Halloysite nanotube-based drug delivery system for treating osteosarcoma. In Proceedings of the 36th Annual International Conference of the IEEE Engineering in Medicine and Biology Society, Chicago, IL, USA, 26-30 August 2014; pp. 2920-2923.

124. Long, Z.R.; Zhang, J.; Shen, Y.; Zhou, C.R.; Liu, M.X. Polyethyleneimine grafted short halloysite nanotubes for gene delivery. Mater. Sci. Eng. C Mater. Biol. Appl. 2017, 81, 224-235. [CrossRef] [PubMed]

125. Jana, S.; Kondakova, A.V.; Shevchenko, S.N.; Sheval, E.V.; Gonchar, K.A.; Timoshenko, V.Y.; Vasiliev, A.N. Halloysite nanotubes with immobilized silver nanoparticles for anti-bacterial application. Colloid Surf. B Biointerfaces 2017, 151, 249-254. [CrossRef] [PubMed]

126. Tham, W.L.; Poh, B.T.; Mohd Ishak, Z.A.; Chow, W.S. Transparent poly(lactic acid)/halloysite nanotube nanocomposites with improved oxygen barrier and antioxidant properties. J. Ther. Anal. Calorim. 2016, 126, 1331-1337. [CrossRef]

127. Vergaro, V.; Lvov, Y.M.; Leporatti, S. Halloysite clay nanotubes for resveratrol delivery to cancer cells. Macromol. Biosci. 2012, 12, 1265-1271. [CrossRef] [PubMed]

128. Hari, J.; Gyurki, A.; Sarkozi, M.; Foldes, E.; Pukanszky, B. Competitive interactions and controlled release of a natural antioxidant from halloysite nanotubes. J. Colloid Interface Sci. 2016, 462, 123-129. [CrossRef] [PubMed]

129. Zhong, B.C.; Lin, J.; Liu, M.L.; Jia, Z.X.; Luo, Y.F.; Jia, D.M.; Liu, F. Preparation of halloysite nanotubes loaded antioxidant and its antioxidative behaviour in natural rubber. Polym. Degrad. Stab. 2017, 141, $19-25$. [CrossRef]

130. Fu, Y.; Zhao, D.T.; Yao, P.J.; Wang, W.C.; Zhang, L.Q.; Lvov, Y. Highly aging-resistant elastomers doped with antioxidant-loaded clay nanotubes. ACS Appl. Mater. Interfaces 2015, 7, 8156-8165. [CrossRef] [PubMed]

131. Zhang, Y.Y.; Gao, R.; Liu, M.; Shi, B.M.; Shan, A.S.; Cheng, B.J. Use of modified halloysite nanotubes in the feed reduces the toxic effects of zearalenone on sow reproduction and piglet development. Theriogenology 2015, 83, 932-941. [CrossRef] [PubMed] 
132. Gao, R.; Meng, Q.W.; Li, J.N.; Zhang, Y.Y.; Bi, C.P.; Shan, A.S. Modified halloysite nanotubes reduce the toxic effects of zearalenone in gestating sows on growth and muscle development of their offsprings. J. Anim. Sci. Biotechnol. 2016, 7, 14. [CrossRef] [PubMed]

133. Zhang, Y.Y.; Gao, R.; Liu, M.; Yan, C.J.; Shan, A.S. Adsorption of modified halloysite nanotubes in vitro and the protective effect in rats exposed to zearalenone. Arch. Anim. Nutr. 2014, 68, 320-335. [CrossRef] [PubMed]

134. Jia, Z.Q.; Yin, S.T.; Liu, M.; Zhang, Y.Y.; Gao, R.; Shi, B.M.; Shan, A.S.; Chen, Z.H. Modified halloysite nanotubes and the alleviation of kidney damage induced by dietary zearalenone in swine. Food Addit. Contam. Part A Chem. Anal. Control Expo. Risk Assess. 2015, 32, 1312-1321. [CrossRef] [PubMed]

135. Fakhrullina, G.I.; Akhatova, F.S.; Lvov, Y.M.; Fakhrullin, R.F. Toxicity of halloysite clay nanotubes in vivo: A caenorhabditis elegans study. Environ. Sci. Nano 2015, 2, 54-59. [CrossRef]

136. Fastov, S.A.; Terent'ev, A.O.; Fastov, I.S.; Firstova, V.V.; Kalmantaeva, O.V. Study of halloysite clay nanotube toxicity as related to their structure. In Abstracts of Papers of the American Chemical Society; American Chemical Society: Washington, DC, USA, 2013; Volume 245.

137. Cardoso, M.M.; Peca, I.N.; Roque, A.C.A. Antibody-conjugated nanoparticles for therapeutic applications. Curr. Med. Chem. 2012, 19, 3103-3127. [CrossRef] [PubMed]

138. Carter, T.; Mulholland, P.; Chester, K. Antibody-targeted nanoparticles for cancer treatment. Immunotherapy 2016, 8, 941-958. [CrossRef] [PubMed]

139. Welch, N.G.; Scoble, J.A.; Muir, B.W.; Pigram, P.J. Orientation and characterization of immobilized antibodies for improved immunoassays. Biointerphases 2017, 12, 02D301. [CrossRef] [PubMed]

140. Kumada, Y. Site-specific immobilization of recombinant antibody fragments through material-binding peptides for the sensitive detection of antigens in enzyme immunoassays. Biochim. Biophys. Acta-Proteins Proteom. 2014, 1844, 1960-1969. [CrossRef] [PubMed]

141. Rusmini, F.; Zhong, Z.; Feijen, J. Protein immobilization strategies for protein biochips. Biomacromolecules 2007, 8, 1775-1789. [CrossRef] [PubMed]

142. Duval, F.; van Beek, T.A.; Zuilhof, H. Key steps towards the oriented immobilization of antibodies using boronic acids. Analyst 2015, 140, 6467-6472. [CrossRef] [PubMed]

143. Kim, H.-J.; Kim, S.-H.; Lee, J.-K.; Choi, C.-U.; Lee, H.-S.; Kang, H.-G.; Cha, S.-H. A novel mycotoxin purification system using magnetic nanoparticles for the recovery of aflatoxin B1 and zearalenone from feed. J. Vet. Sci. 2012, 13, 363-369. [CrossRef] [PubMed]

144. Xiong, Y.; Tu, Z.; Huang, X.; Xie, B.; Xiong, Y.; Xu, Y. Magnetic beads carrying poly(acrylic acid) brushes as "nanobody containers" for immunoaffinity purification of aflatoxin $B_{1}$ from corn samples. RSC Adv. 2015, 5, 77380-77387. [CrossRef]

145. Ali, I.; Peng, C.S.; Khan, Z.M.; Naz, I. Yield cultivation of magnetotactic bacteria and magnetosomes: A review. J. Basic Microbiol. 2017, 57, 643-652. [CrossRef] [PubMed]

146. Lin, W.; Pan, Y.X.; Bazylinski, D.A. Diversity and ecology of and biomineralization by magnetotactic bacteria. Environ. Microbiol. Rep. 2017, 9, 345-356. [CrossRef] [PubMed]

147. Pi, F.; Sun, J.; Liu, W.; Sun, X.; Zhang, Y. Elimination of aflatoxin $B_{1}$ in vegetable oil based on immunomagnetosomes probes from a novel magnetotactic bacterium. Food Control 2017, 80, 319-326. [CrossRef]

148. Awad, W.A.; Ghareeb, K.; Dadak, A.; Hess, M.; Bohm, J. Single and combined effects of deoxynivalenol mycotoxin and a microbial feed additive on lymphocyte DNA damage and oxidative stress in broiler chickens. PLoS ONE 2014, 9, e88028. [CrossRef] [PubMed]

149. Hou, Y.J.; Zhao, Y.Y.; Xiong, B.; Cui, X.S.; Kim, N.H.; Xu, Y.X.; Sun, S.C. Mycotoxin-containing diet causes oxidative stress in the mouse. PLoS ONE 2013, 8, e60374. [CrossRef] [PubMed]

150. Horky, P.; Skladanka, J.; Nevrkla, P.; Slama, P. Effect of diet supplemented with antioxidants (selenium, copper, vitamins $\mathrm{E}$ and $\mathrm{C}$ ) on antioxidant status and ejaculate quality of breeding boars. Ann. Anim. Sci. 2016, 16, 521-532. [CrossRef]

151. Horky, P.; Ruttkay-Nedecky, B.; Kremplova, M.; Krystofova, O.; Kensova, R.; Hynek, D.; Babula, P.; Zitka, O.; Zeman, L.; Adam, V.; et al. Effect of different doses of organically bound selenium on antioxidant status and levels of metal ions in postpartum sows. Int. J. Electrochem. Sci. 2013, 8, 6162-6179.

152. Skalickova, S.; Milosavljevic, V.; Cihalova, K.; Horky, P.; Richtera, L.; Adam, V. Selenium nanoparticles as a nutritional supplement. Nutrition 2017, 33, 83-90. [CrossRef] [PubMed] 
153. Kovacic, P.; Somanathan, R. Biomechanisms of nanoparticles (toxicants, antioxidants and therapeutics): Electron transfer and reactive oxygen species. J. Nanosci. Nanotechnol. 2010, 10, 7919-7930. [CrossRef] [PubMed]

154. Nelson, B.C.; Johnson, M.E.; Walker, M.L.; Riley, K.R.; Sims, C.M. Antioxidant cerium oxide nanoparticles in biology and medicine. Antioxidants 2016, 5, 15. [CrossRef] [PubMed]

155. Raveendran, P.; Fu, J.; Wallen, S.L. Completely "green" synthesis and stabilization of metal nanoparticles. J. Am. Chem. Soc. 2003, 125, 13940-13941. [CrossRef] [PubMed]

156. Kohli, E.; Raj, H.G.; Kumari, R.; Rohil, V.; Kaushik, N.K.; Prasad, A.K.; Parmar, V.S. Comparison of the prevention of aflatoxin $\mathrm{B}_{1}$-induced genotoxicity by quercetin and quercetin pentaacetate. Bioorg. Med. Chem. Lett. 2002, 12, 2579-2582. [CrossRef]

157. Choi, K.C.; Chung, W.T.; Kwon, J.K.; Yu, J.Y.; Jang, Y.S.; Park, S.M.; Lee, S.Y.; Lee, J.C. Inhibitory effects of quercetin on aflatoxin $\mathrm{B}_{1}$-induced hepatic damage in mice. Food Chem. Toxicol. 2010, 48, 2747-2753. [CrossRef] [PubMed]

158. Periasamy, R.; Kalal, I.G.; Krishnaswamy, R.; Viswanadha, V. Quercetin protects human peripheral blood mononuclear cells from OTA-induced oxidative stress, genotoxicity, and inflammation. Environ. Toxicol. 2016, 31, 855-865. [CrossRef] [PubMed]

159. Abbas, Z.; Blank, R.; Wein, S.; Wolffram, S. Effect of quercetin on the toxicokinetics of ochratoxin A in rats. Food Addit. Contam. Part A Chem. Anal. Control Expo. Risk Assess. 2013, 30, 861-866. [CrossRef] [PubMed]

160. Orsolic, N.; Jazvinscak Jembrek, M.; Terzic, S. Honey and quercetin reduce ochratoxin A-induced DNA damage in the liver and the kidney through the modulation of intestinal microflora. Food Agric. Immunol. 2017, 28, 812-833. [CrossRef]

161. Lesniak-Walentyn, A.; Kolesarova, A.; Medvedova, M.; Maruniakova, N.; Capcarova, M.; Kalafova, A.; Hrabia, A.; Sirotkin, A.V. Proliferation and apoptosis in the rabbit ovary after administration of T-2 toxin and quercetin. J. Anim. Feed Sci. 2013, 22, 264-271. [CrossRef]

162. Ben Salem, I.; Prola, A.; Boussabbeh, M.; Guilbert, A.; Bacha, H.; Lemaire, C.; Abid-Essefi, S. Activation of ER stress and apoptosis by alpha- and beta-zearalenol in HCT116 cells, protective role of Quercetin. Neurotoxicology 2016, 53, 334-342. [CrossRef] [PubMed]

163. Ben Salem, I.; Prola, A.; Boussabbeh, M.; Guilbert, A.; Bacha, H.; Abid-Essefi, S.; Lemaire, C. Crocin and quercetin protect $\mathrm{HCT}_{116}$ and $\mathrm{HEK}_{293}$ cells from Zearalenone-induced apoptosis by reducing endoplasmic reticulum stress. Cell Stress Chaperones 2015, 20, 927-938. [CrossRef] [PubMed]

164. Fernandez-Blanco, C.; Font, G.; Ruiz, M.-J. Role of quercetin on Caco-2 cells against cytotoxic effects of alternariol and alternariol monomethyl ether. Food Chem. Toxicol. 2016, 89, 60-66. [CrossRef] [PubMed]

165. Abdel-Wahhab, M.A.; Aljawish, A.; El-Nekeety, A.A.; Abdel-Aziem, S.H.; Hassan, N.S. Chitosan nanoparticles plus quercetin suppress the oxidative stress, modulate DNA fragmentation and gene expression in the kidney of rats fed ochratoxin A-contaminated diet. Food Chem. Toxicol. 2017, 99, $209-221$. [CrossRef] [PubMed]

166. Sun, G.Y.; Chen, Z.H.; Jasmer, K.J.; Chuang, D.Y.; Gu, Z.Z.; Hannink, M.; Simonyi, A. Quercetin attenuates inflammatory responses in BV-2 microglial cells: Role of MAPKs on the nrf2 pathway and induction of heme oxygenase-1. PLoS ONE 2015, 10, e0141509. [CrossRef] [PubMed]

167. Oberdorster, G.; Oberdorster, E.; Oberdorster, J. Nanotoxicology: An emerging discipline evolving from studies of ultrafine particles. Environ. Health Perspect. 2005, 113, 823-839. [CrossRef] [PubMed]

168. Kaundal, B.; Dalai, S.; Choudhury, S.R. Nanomaterial toxicity in microbes, plants and animals. In Nanoscience in Food and Agriculture 5; Ranjan, S., Dasgupta, N., Lichtfouse, E., Eds.; Springer International Publishing: Cham, Switzerland, 2017; pp. 243-266.

169. Suresh, A.K.; Pelletier, D.A.; Doktycz, M.J. Relating nanomaterial properties and microbial toxicity. Nanoscale 2013, 5, 463-474. [CrossRef] [PubMed]

170. Chatterjee, S.; Kumari, R.M.; Nimesh, S. Nanotoxicology: Evaluation of toxicity potential of nanoparticles. In Advances in Nanomedicine for the Delivery of Therapeutic Nucleic Acids; Nimesh, S., Chandra, R., Gupta, N., Eds.; Elsevier: New York City, NY, USA, 2017; pp. 187-201.

171. Jo, H.Y.; Kim, Y.; Park, H.W.; Moon, H.E.; Bae, S.; Kim, J.; Kim, D.G.; Paek, S.H. The unreliability of MTT assay in the cytotoxic test of primary cultured glioblastoma cells. Exp. Neurobiol. 2015, 24, 235-245. [CrossRef] [PubMed] 
172. Bondarenko, O.; Juganson, K.; Ivask, A.; Kasemets, K.; Mortimer, M.; Kahru, A. Toxicity of Ag, CuO and ZnO nanoparticles to selected environmentally relevant test organisms and mammalian cells in vitro: A critical review. Arch. Toxicol. 2013, 87, 1181-1200. [CrossRef] [PubMed]

173. Wang, Z.Y.; Zhang, L.; Zhao, J.; Xing, B.S. Environmental processes and toxicity of metallic nanoparticles in aquatic systems as affected by natural organic matter. Environ. Sci. Nano 2016, 3, 240-255. [CrossRef]

174. Goyal, P.; Basniwal, R.K. Toxicity of nanoparticles and their impact on environment. In Nanoscience and Plant-Soil Systems; Ghorbanpour, M., Khanuja, M., Varma, A., Eds.; Springer: Berlin, Germany, 2017; Volume 48, pp. 531-543.

175. Alshannaq, A.; Yu, J.H. Occurrence, toxicity, and analysis of major mycotoxins in food. Int. J. Environ. Res. Public Health 2017, 14, 632. [CrossRef] [PubMed]

176. Kharisov, B.I.; Kharissova, O.V.; Chavez-Guerrero, L. Synthesis techniques, properties, and applications of nanodiamonds. Synth. React. Inorg. Met.-Org. Nano-Met. Chem. 2010, 40, 84-101.

177. Moore, L.; Yang, J.Y.; Lang, T.T.H.; Osawa, E.; Lee, D.K.; Johnson, W.D.; Xi, J.Z.; Chow, E.K.H.; Ho, D. Biocompatibility assessment of detonation nanodiamond in non-human primates and rats using histological, hematologic, and urine analysis. ACS Nano 2016, 10, 7385-7400. [CrossRef] [PubMed]

178. Sherlala, A.I.A.; Raman, A.A.A.; Bello, M.M.; Asghar, A. A review of the applications of organo-functionalized magnetic graphene oxide nanocomposites for heavy metal adsorption. Chemosphere 2018, 193, 1004-1017. [CrossRef] [PubMed]

179. Liu, J.H.; Wang, T.C.; Wang, H.F.; Gu, Y.G.; Xu, Y.Y.; Tang, H.; Jia, G.; Liu, Y.F. Biocompatibility of graphene oxide intravenously administrated in mice-effects of dose, size and exposure protocols. Toxicol. Res. 2015, 4, 83-91. [CrossRef]

180. Cervini-Silva, J.; Palacios, E.; Gomez-Vidales, V. Nontronite as natural source and growth template for (nano)maghemite gamma- $\mathrm{Fe}_{2} \mathrm{O}_{3}$ and (nano)wustite $\mathrm{Fe}_{1-\mathrm{x}} \mathrm{O}$. Appl. Clay Sci. 2018, 156, 178-186. [CrossRef]

181. Shen, J.M.; Huang, G.; Zhou, X.; Zou, J.; Yang, Y.; Chen, Y.F.; Men, S.K. Safety evaluation of graphene oxide-based magnetic nanocomposites as mri contrast agents and drug delivery vehicles. RSC Adv. 2014, 4, 50464-50477. [CrossRef]

182. Divya, K.; Jisha, M.S. Chitosan nanoparticles preparation and applications. Environ. Chem. Lett. 2018, 16, 101-112. [CrossRef]

183. Bowman, K.; Leong, K.W. Chitosan nanoparticles for oral drug and gene delivery. Int. J. Nanomed. 2006, 1, 117-128. [CrossRef]

184. Wang, X.Y.; Du, Y.M.; Luo, J.W. Biopolymer/montmorillonite nanocomposite: Preparation, drug-controlled release property and cytotoxicity. Nanotechnology 2008, 19, 065707. [CrossRef] [PubMed]

185. Baek, M.; Lee, J.A.; Choi, S.J. Toxicological effects of a cationic clay, montmorillonite in vitro and in vivo. Mol. Cell. Toxicol. 2012, 8, 95-101. [CrossRef]

(C) 2018 by the authors. Licensee MDPI, Basel, Switzerland. This article is an open access article distributed under the terms and conditions of the Creative Commons Attribution (CC BY) license (http://creativecommons.org/licenses/by/4.0/). 